\title{
„LESK A BÍDA“ INTEGRACE CIZINCŮ POHLEDEM VLÁDNÍCH KONCEPCÍ INTEGRACE CIZINCŮ (S VYUŽITÍM KAZUISTIK Z PRAXE VEŘEJNÉHO OCHRÁNCE PRÁV)
}

\author{
PAVEL POŘÍZEK
}

\begin{abstract}
The "Splendors and Miseries" of Integration of Foreigners from the Perspective of the Governmental Policies for the Integration of Foreign Nationals (in the Light of Case Studies as Tested by the Public Defender of Rights)

The article deals with the conditions of integration of foreigners in the Czech Republic. The information used for the analysis and conclusions of the article draws mainly on governmental policies for integration of foreigners. The key areas of integration include knowledge of the Czech language, economic and social self-sufficiency, socio-cultural orientation within the society, and relations among communities. The policies openly exemplify failures of governmental integration measures. Several examples are mentioned, such as: the relevant Ministries suffering from being understaffed or insufficiently involved; further insufficient involvement of municipalities in integration activities; and delays in implementation of a wide range of integration measures. Several issues remain unsolved, including the participation of children of third country nationals in the national health insurance scheme or enabling the foreigners permanently residing in the territory of the Czech Republic to exercise their right to vote in municipal elections. Both the mentioned policies and this article point out two topics of gravity: the first one being the complex nature of relevant legal sources and provisions which makes the legal sources appear difficult to access; the second one rests in the fact that the vast majority of foreigners remains reliant on services of dubious agents and mediators.

In spite of all of the aforementioned hindrances foreigners integrate successfully, and demonstrate ability to access and enter the labor market. The percentage of foreigners collecting social benefits is negligible. No relevant information available indicates that they represent a threat to national security. In spite of certain reservations on the side of the majority the co-existence of the majority with foreigners is described as lacking in conflict. There is clear evidence supporting the notion that foreigners aim at integration with the majority and that the value system of the three biggest groups of foreigners divided by nationality (Ukrainian, Vietnamese and Russian) overlaps to a large extent with the value system of the majority. The development and trends in the influx of foreigners to the Czech Republic show that so far since 1989 there has been a thirteen fold increase in the number of foreigners and over half a million foreigners have been integrated. Foreigners appear to integrate well despite insufficiently structured and targeted integration measures. However, the topic of integration of foreigners with respect to the forecasted significant and continuous increase in their influx should be viewed as a matter of importance that needs to be provided both financial means and targeted effort.
\end{abstract}

Keywords: citizenship; naturalisation; integration

Klíčová slova: státní občanství; naturalizace; integrace

DOI: $10.14712 / 23366478.2018 .5$ 


\section{1. ÚVODEM}

Smyslem př́spěvku bude zamyšlení se nad stavem integrace cizinců v České republice. Daří se jí realizovat cíl integrační politiky, kterým je „,podpořit začlenění cizinců do společnosti, docílit klidné soužití s cizinci, zamezit vzniku negativních sociálních jevů a zajistit ochranu práv a bezpečnost všech obyvatel České republiky“"? Jak účinná jsou opatření státu ve čtyřech, resp. pěti klíčových oblastech integrace, kterými jsou znalost českého jazyka, ekonomická a sociální soběstačnost, sociokulturní orientace ve společnosti, vztahy mezi komunitami a princip postupného nabývání práv cizinců v návaznosti na postupné nabývání vyšších pobytových statusů na území České republiky $?^{2}$ Integrují se cizinci úspěšně nebo naopak v některých oblastech jejich začlenění pokulhává? Jakým výzvám cizinci při integraci čelí? Jsou prostředky státu vynakládané na integraci cizinců dostatečné? To jsou některé z otázek, na které se pokusím ve svém př́spěvku najít stručnou odpověd'. Průběžně se zaměřím i na vybrané kauzy související s integrací cizinců, které při výkonu své působnosti řešil veřejný ochránce práv. Na nich budu demonstrovat, že v řadě oblastí integrační opatření státu selhávají, popř. nejsou dostatečná a proces integrace cizincům znesnadňují. V tomto ohledu jsou názorné jednotlivé koncepce integrace cizinců, které často velmi otevřeně popisují nedostatečnost opatření přijímaných státem $\mathrm{v}$ různých oblastech integrace cizincủ. Uvidíme, že při srovnání jednotlivých koncepcí integrace cizinců, které od sebe dělí pětiletý časový úsek, nedochází v některých oblastech (přes navržená integrační opatření) prakticky k žádnému zlepšení stavu.

\section{INTEGRAČNÍ POLITIKA STÁTU}

Česká republika koncepčně uchopila fenomén integrace cizinců poměrně pozdě, až v roce 1999, kdy byly přijaty Zásady koncepce integrace cizinců na území České republiky (dále jen „Zásady“). ${ }^{3}$ Ve vztahu k cizincům jsou koncipovány velkoryse, ,procizinecky“. Prizmatem současného většinového postoje stávajících politických elit i převažujících nálad ve společnosti zní nepravděpodobně, že zásady otevřeně proklamují snahu České republiky o vytvoření multikulturní společnosti. Imigrační komunity jsou pokládány za integrální a obohacující součást společnosti a za plnohodnotné a nezbytné partnery při vytváření multikulturní společnosti. ${ }^{4}$ Zásady proklamují směřování $\mathrm{k}$ zajištění ochrany a přístupu cizinců $\mathrm{k}$ základním lidským právům a svobodám. ${ }^{5}$

1 Usnesení vlády ze dne 18. ledna 2016 č. 26 o aktualizované Koncepci integrace cizinců - Ve vzájemném respektu a o Postupu při realizaci aktualizované Koncepce integrace cizinců v roce 2016, III., kapitola 2, Aktualizovaná „Koncepce integrace cizinců - Ve vzájemném respektu“, s. 17.

2 Tamtéž, kapitola 3, Postup při realizaci aktualizované Koncepce integrace cizinců v roce 2016, s. 25.

3 Př́loha č. 1 k usnesení vlády ze dne 7. července 1999 č. 698.

4 Zásada č. 2.

5 Zásada č. 4: „Politika vlády v oblasti integrace legálně a dlouhodobě usazených cizinců směřuje zejména k vytvoření legislativně-právních podmínek a koncepce zajištění ochrany a př́istupu cizinců k základním lidským právům a svobodám, včetně politických, hospodářských, sociálních a kulturních práv s ohledem na délku, účel a cíl jejich pobytu na území České republiky jako základnímu předpokladu jejich integrace a rozvoje dobrých vztahů mezi komunitami.“ 
Zdůrazňují pozitivní (a aktivní) přístup státu a jeho odpovědnost ,za vytváření podmínek, které umožní spravedlivou participaci cizinců na životě společnosti.“7 Integrační opatření by měla směřovat $\mathrm{k}$ odstranění diskriminace imigrantů $8 \mathrm{a} \mathrm{k}$,,podpoře rovného př́stupu a rovné příležitosti především na trhu práce, ve vztahu k bydlení, ke vzdělání, zdravotní a sociální péči a náboženství.“9 Dle zásady č. 13: „Vláda podporuje vytváření reálného mediálního obrazu o vztazích mezi komunitami a o možnostech jejich dalšího rozvoje a podpory. Zaměření a cíle v oblasti integrace legálně a dlouhodobě usazených cizinců ... jsou neslučitelné s jakoukoliv formou veřejné diskriminace namířené proti imigračním komunitám nebo jejich př́slušníkům.“10

První koncepce byla přijata usnesením vlády ze dne 11. prosince 2000 č. $1266 .{ }^{11}$ Aktualizována byla v roce 2006, 2011 (Společné soužití) ${ }^{13}$ a naposledy v roce 2016 (Ve vzájemném respektu). ${ }^{14}$ Každoročně jsou vládou rovněž přijímány zprávy o realizaci koncepce integrace cizinců. Koordinační roli v oblasti integrace cizinců plní ministerstvo vnitra. ${ }^{15}$

Jak uvidíme na konkrétních př́padech, původní ambiciózní návrhy ${ }^{16}$ na široké využití katalogu základních lidských práv a svobod usazenými cizinci, obsažené v Zásadách, jsou následnými koncepcemi v některých oblastech opouštěny či zmírňovány (napřs. pokud jde o př́istup cizinců $\mathrm{k}$ veřejnému zdravotnímu pojištění či při realizaci volebního práva na místní úrovni).

${ }^{6}$ Zásady č. 7 a 8.

7 Zásada č. 2. Tato zásada dále pokračuje: „Zaručuje imigrantům možnost přiměřeně, svobodně a plně se podílet na hospodářském, společenském a veřejném životě národa a svobodně udržovat vlastní náboženskou a kulturní identitu." Tato věta v sobě však obsahuje určitý protimluv, nebot' není možné zaručit imigrantům zároveň přiměřenou i plnou možnost participace.

8 Zásada č. 7: „Podpora integrace imigrantů je založena na aktivním přístupu vlády a společnosti směrujícím k odstranění jejich diskriminace a umožňujícím využití hodnot dostupných všem obyvatelům České republiky."

9 Zásada č. 8.

$10 \mathrm{~K}$ tomu srov. např. V Česku už další muslimy nechceme, řekl Sobotka. Hodlá předejít problémům. iDNES [online], 25. 8. 2017. Dostupné z: https://zpravy.idnes.cz/sobotka-muslimove-uprchlici-did-/domaci .aspx?c=A170825_141219_domaci_jj; LIPOLD, J.: Okamura chce zakázat islám. Trumfnul Sobotku. Aktualnè.cz [online], 5. 9. 2017. Dostupné z: https://nazory.aktualne.cz/komentare/okamura-chce-zakazat -islam-trumfnul-sobotku/r d9f7e42c923811e79b440025900fea04/.

11 Bohužel text této koncepce se mi přes veškerou snahu nepodařilo z veřejně (http://www.mvcr.cz/clanek /integrace.aspx, http://cizinci.cz/cs/) i neveřejně (eKLEP) dostupných zdrojů dohledat.

12 Usnesení vlády ze dne 8. února 2006 č. 126. Kriticky hodnotí dosavadní koncepci a přichází s novým pojetím (II. Předkládací zpráva): „Koncepce integrace cizinců byla doposud realizována metodou „mainstreamingu“, aniž by přehledným způsobem vymezovala priority politiky integrace cizinců v České republice v dlouhodobějším horizontu. V rámci aktualizované Koncepce integrace cizinců jsou navrhována cílená specifická opatření, čímž jsou stanoveny prioritní oblasti vládní politiky integrace cizinců. Vymezena jsou dále opatření podpůrná, tj. taková, která procesu integrace napomáhaji..“

13 Usnesení vlády ze dne 9. února 2011 č. 99.

14 Usnesení vlády ze dne 18 . ledna 2016 č. 26.

15 Pouze v období od 1. ledna 2004 (na základě usnesení vlády ze dne 10. prosince 2003 č. 1252) do července 2008 (usnesení vlády ze dne 23. července 2008 č. 979) plnilo tuto roli Ministerstvo práce a sociálních věcí.

$16 \mathrm{~V}$ tomto ohledu lze ocenit např. důkladnou Analýzu situace a postavení cizinců dlouhodobě žijících na území České republiky (usnesení vlády ze dne 11. února 2004 č. 129, př́iloha č. 1) a Návrhy legislativních a praktických opatření ministerstev v rámci Koncepce integrace cizinců v souvislosti se vstupem České republiky do Evropské unie (tamtéž, př́loha č. 2). 
V České republice prozatím neexistuje zvláštní právní předpis (zákon), ${ }^{17}$ který by se zabýval výhradně integrací cizinců (uprchlíků), jako je tomu v řadě jiných členských států Evropské unie. ${ }^{18}$ Integrace cizince doposud není jeho povinností, ale pouze právem. Legislativa $\mathrm{v}$ ČR tedy prozatím nezná a nepoužívá instrumenty jako je např. integrační kontrakt či smlouva. Pouze k získání trvalého pobytu musí od roku 2009 cizinci - občané třetích zemí (občanem třetí země je občan státu, který není členem EU a není zároveň občanem Islandu, Lichtenštejnska, Norska a Švýcarska) předložit doklad prokazující požadovanou znalost českého jazyka, ${ }^{19}$ která byla stanovena na úrovni A1 (tedy nejnižší) Společného evropského referenčního rámce pro jazyky (SERR). ${ }^{20}$ Až aktuálně (t. č. v meziresortním připomínkovém řízení) projednávaná novela zákona o pobytu cizinců zavádí pro všechny cizince s dlouhodobým a trvalým pobytem povinnost absolvovat do jednoho roku od vydání povolení adaptačně integrační kurz (nově navrhovaný § 155 b zákona o pobytu cizinců).

\section{CÍLOVÁ SKUPINA}

Přesně vyčíslit cílovou skupinu integračních opatření není vůbec jednoduché. Jednotlivé koncepce navíc vymezení cílové skupiny měnily. Základní cílovou skupinu integračních opatření tvoří občané třetích zemí, dlouhodobě legálně pobývající na území České republiky. Požadavek na dlouhodobý legální pobyt znamená, že by měli na území České republiky pobývat v souladu s cizineckou legislativou nejméně jeden rok. ${ }^{21}$ Nepůjde tedy o cizince, kteří na území ČR pobývají na základě krátkodobého, ale ani dlouhodobého víza. ${ }^{22}$ Pokud jde o cizince s dlouhodobým pobytem, pokud na dlouhodobý pobyt přechází z dlouhodobého víza, není s jejich podřazením pod cílovou skupinu problém. Dnes ovšem většina dlouhodobých pobytů vychází z unijních směrnic a lze o ně žádat př́mo z třetí země, aniž by občan třetí země musel (mohl) disponovat předchozím dlouhodobým vízem. Občané třetích zemí se směrnicovým dlouhodobým pobytem tak během prvního roku pobytu nemusí spadat do cílové skupiny. ${ }^{23} \mathrm{Na}$ druhé

17 Stojí za zmínku, že již usnesení vlády ze dne 5. ledna 2005 č. 5 (IV. Postup při realizaci koncepce v roce 2005 , s. 19) uvádí, že „bude-li Česká republika preferovat aktivní př́stup k otázce integrace cizinců, tj. usilovat o stanovení integračních požadavků a korespondujících práv imigrantů, je jedinou možností detailní právní úprava, která přesně vymezí vzájemná práva a povinnosti a zajistí potřebnou transparentnost a předvídatelnost právního postavení imigranta“ (důraz převzat). K tomu nikdy nedošlo.

18 Viz napřr. rakouský Integrationsgesetz z roku 2017.

19 Viz $§ 70$ odst. 2 písm. h) zákona o pobytu cizinců.

20 Viz nařízení vlády č. 31/2016 Sb., o prokazování znalosti českého jazyka pro účely získání povolení $\mathrm{k}$ trvalému pobytu.

21 Viz usnesení vlády ze dne 8. února 2006 č. 126, III. Aktualizovaná Koncepce integrace cizinců, s. 16.

22 Maximální doba platnosti dlouhodobého víza je jeden rok, resp. půl roku u dlouhodobého víza za účelem sezónního zaměstnání (§ 30 odst. 3 zákona č. 326/1999 Sb., o pobytu cizinců na území České republiky a o změně některých zákonů, ve znění pozdějších předpisů, dále jen „zákon o pobytu cizincư“).

23 Zároveň však výše zmíněná novela zákona o pobytu cizinců zavádí pro všechny cizince s dlouhodobým pobytem povinnost absolvovat do jednoho roku od vydání povolení adaptačně integrační kurz. Je př́iznačné, že povinnost absolvování adaptačně integračních kurzů zmiňuje již usnesení vlády ze dne 9. února 2011 č. 99, III., Kapitola 1. Analýza aktuální situace v oblasti integrace cizinců na území České republiky, s. 19. Tato povinnost se však do zákona o pobytu cizinců dostane nejdř́ive v roce 2018. 
straně koncepce postupně začínají některá integrační opatření směřovat již vůči nově legálně prííchozím cizincům, ${ }^{24}$ resp. ještě do předodjezdové fáze (tzv. přijímací balíčky). ${ }^{25}$

Občané třetích zemí s trvalým pobytem budou obecně do cílové skupiny spadat, i když i u nich lze identifikovat kategorie osob, které mohou trvalý pobyt nabýt, aniž by předtím na území alespoň jeden rok legálně pobývaly. ${ }^{26}$

Občané EU původně cílovou skupinu integrace cizinců netvořili. ${ }^{27}$ Pod ní ji podřadila až aktualizovaná koncepce integrace cizinců Společné soužití z roku 2011. ${ }^{28}$ Naproti tomu rodinní prríslušníci občanů EU/ČR z třetích zemí, pobývající na území na základě přechodného pobytu, do cílové skupiny spadají (striktně vzato až po uplynutí jednoho roku pobytu na území). Ti tvoří až jednu třetinu všech cizinců z třetích zemí dlouhodobě pobývajících na území ČR. ${ }^{29} \mathrm{~V}$ prrípadě potřeby mohou relevantních integračních nástrojů využít i držitelé mezinárodní ochrany, ${ }^{30}$ nikoli však žadatelé o tuto ochranu. Postupně se cílovou skupinou integrace stali také občané ČR, nebot' „integrace je obousměrným procesem a jejím předpokladem je vzájemná interakce mezi cizinci a majoritou“. ${ }^{31}$

Pokud jde o počty cizinců (včetně občanů EU) na území ČR, k 31. 12. 2016 jich pobývalo na území České republiky legálně (po dobu delší než 90 dnů) celkem $496413^{32}$ a tvořili zhruba 4,7 \% populace České republiky. ${ }^{33} 273399$ cizinců (55,1 \%,

24 Viz např. usnesení vlády ze dne 16. února 2009 č. 183 ke Zprávě o realizaci Koncepce integrace cizinců v roce 2008, IV. Postup při realizaci Koncepce integrace cizinců v roce 2009, s. 13: „Současná situace však zásadním způsobem relativizuje dosud platné definování cílové skupiny. Vzhledem k aktuální situaci, dosavadním zkušenostem a potřebám integrace proto musí být cílová skupina nově definována. Politika integrace cizinců bude tedy zacílena i na nově př́íchozí cizince s legálním pobytem v České republice (at' již za účelem sloučení rodiny, nebo za účelem zaměstnání, podnikání atd.), se záměrem umožnit jim základní orientaci v hostitelské zemi. “ Lze odkázat též na usnesení vlády ze dne 9. února 2011 č. 99, III., Kapitola 1. Analýza aktuální situace v oblasti integrace cizinců na území České republiky, s. 18, 19.

25 Viz usnesení vlády ze dne 9. února 2011 č. 99, III., Kapitola 2. Aktualizovaná Koncepce integrace cizinců Společné soužití, s. $18,19$.

26 Obecně lze trvalý pobyt získat po pěti letech předchozího pobytu na území [§ 68, resp. 87h odst. 1 písm. a) zákona o pobytu cizinců; cizincům z třetích zemí - rodinným př́ílušníkủm občanů ČR, stačí dva roky předchozího přechodného pobytu, viz $\S 87 \mathrm{~h}$ odst. 1 písm. b) téhož zákona].

27 Viz usnesení vlády ze dne 8. února 2006 č. 126, III. Aktualizovaná Koncepce integrace cizinců, s. 16.

28 Usnesení vlády ze dne 9. února 2011 č. 99, III., kapitola 2., Aktualizovaná Koncepce integrace cizinců Společné soužití, s. 18: „Nově budou moci v případě nezbytné potřeby některá integrační opatř̌ení využít výjimečně rovněž občané jiných členských zemí Evropské unie.“ Koncepce z roku 2016 (Ve vzájemném respektu) k tomu uvádí: „Občané EU pobývající na území jako dodatková cílová skupina mají možnost využívat některých integračních nástrojů (poskytování informací a informačních materiálů, pomoc v osobní krizové situaci).“ (usnesení vlády ze dne 18. ledna 2016 č. 26, III., kapitola 3, Postup při realizaci aktualizované Koncepce integrace cizincủ v roce 2016, s. 25).

29 Usnesení vlády ze dne 18. ledna 2016 č. 26, III., kapitola 1, Analýza aktuální situace v oblasti integrace cizinců na území České republiky, s. 2.

30 Tedy nejen azylanti, ale i osoby s udělenou doplňkovou ochranou. Viz usnesení vlády ze dne 18. ledna 2016 č. 26, III., kapitola 3, Postup při realizaci aktualizované Koncepce integrace cizinců v roce 2016, s. 25. Původně tvořili cílovou skupinu integrace azylanti (usnesení vlády ze dne 8 . února 2006 č. 126). Koncepce z roku 2011 s nimi naopak nepočítala (usnesení vlády ze dne 9. února 2011 č. 99).

31 Usnesení vlády ze dne 22. března 2010 č. 224 ke Zprávě o realizaci Koncepce integrace cizinců v roce 2009, IV. Postup při realizaci Koncepce integrace cizinců v roce 2010, s. 32.

32 K 30. 9. 2017 to bylo již 516983 osob (ČSÚ. Počet cizinců v ČR - předběžné čtvrtletni údaje; 2004/06 2017/09 [online]. Dostupné z: https://www.czso.cz/documents/11292/44321488/c01R02_201709.pdf /d5111138-1697-4739-8e61-e24b424d6158?version=1.0).

33 Ministerstvo vnitra. Zpráva o situaci v oblasti migrace a integrace cizinců na území České republiky $v$ roce 2016 , s. 63,64 . [online]. Dostupné z: http://www.mvcr.cz/clanek/migracni-a-azylova-politika -ceske-republiky-470144.aspx?q=Y2hudW09NA\%3D\%3D. 
např. u Vietnamců je tomu $83,6 \%{ }^{34}$ ) pobývalo v ČR s povolením $\mathrm{k}$ trvalému pobytu a 223014 přechodně. ${ }^{35}$ Jde o zajímavý trend, kdy počet cizinců s uděleným trvalým pobytem kontinuálně narůstá již více než 10 let. Od roku 2013 většina cizinců pobývajících na území ČR disponuje povolením k trvalému pobytu. ${ }^{36} 209078$ cizinců $(42,1 \%)$ představují občané EU, zbytek $(287335,57,9 \%)$ tvořili občané třetích zemí. ${ }^{37}$ Zastoupení cizinců pobývajících v ČR dle jejich státní prríslušnosti, je dlouhodobě takřka neměnné. Zhruba 55,5 \% cizinců s povoleným pobytem na území ČR tvoří státní př́slušníci těchto 3 zemí: Ukrajiny (110 245 osob k 31. 12. 2016), Slovenska (107 251) a Vietnamu (58 080). Ostatní státní př́íslušnosti následují s výraznějším odstupem. ${ }^{38}$ U cizinců $\mathrm{z}$ třetích zemí jednoznačně dominují osoby ve věku od 15 do 64 let, tvoří více než 83 procent z celkového počtu občanů tretích zemí. ${ }^{39}$ Naproti tomu podle prognóz Českého statistického úrúadu klesne koncem století podíl obyvatel ČR v produktivním věku ze současných $70 \%$ na $55 \%$. Zastoupení seniorů ve věku 65 let a více se zvýší ze současné jedné šestiny na jednu třetinu. ${ }^{40}$

Jen pro srovnání, ke konci roku 1992 žilo na území tehdejší České republiky jen 49957 cizinců. ${ }^{41}$ Za 24 let od vzniku samostatné České republiky tak narostl jejich počet téměř desetinásobně, od roku 1989 třináctinásobně. ${ }^{42}$ Jde o významný nárůst počtu cizinců, který ČR zvládla bez výraznějších potíží vstř̌ebat. Některé meziroční přírůstky působí až impozantně: 2006/2007 - 70 631, 1994/1995 - 54864 či 2007/2008 - 44214. Na některých údajích lze zároveň demonstrovat výrazné proměny vládní migrační politiky vůči státům s nevyšším migračním potenciálem do České republiky. Obecně lze konstatovat, že od roku 2009 v důsledku dopadů tehdejší ekonomické krize je migrační politika státu (nejen) vǔči těmto zemím podstatně restriktivnější a meziroční nárůsty počtu cizinců jsou oproti předchozím letům podstatně skrovnější (v letech 2009/2010 došlo dokonce $\mathrm{k}$ poklesu). Viděno dnešní situací se tak zdá až neuvěřitelné, že např. v roce 2008 umožnila Česká republika podat z Vietnamu 33742 žádostí o dlouhodobé vízum

34 Tamtéž, s. 66.

35 Tamtéž, s. 64. Přechodným pobytem se má na mysli pobyt cizince s dlouhodobým vízem, povolením k dlouhodobému pobytu, potvrzením o přechodném pobytu občana EU či povolením k přechodnému pobytu rodinného př́slušníka občana EU.

36 Tamtéž, s. 65.

37 Tamtéž.

38 Tamtéž.

39 Usnesení vlády ze dne 18. ledna 2016 č. 26, III., kapitola 1, Analýza aktuální situace v oblasti integrace cizinců na území České republiky, s. 3. Viz rovněž usnesení vlády ze dne 9. února 2011 č. 99, III., kapitola 1. Analýza aktuální situace v oblasti integrace cizinců na území České republiky, s. 7: „Z hlediska věkové struktury mezi cizinci ze třetích zemí jednoznačně dominují dospělé osoby v produktivním věku 19-55 let (přes $81 \%$ z celkového počtu cizincủ ze třetích zemí). Na rozdíl od věkové struktury obyvatelstva České republiky je mezi cizinci podíl osob v post produktivním věku (nad 65 let) výrazně nižší, jejich počet nedosahuje ani $2 \%$ (5 421 osob).“

40 ČSÚ. Projekce obyvatelstva České republiky (Projekce 2013). [online]. Dostupné z: https://www.czso.cz /documents/10180/20567167/402013u.pdf/3cdc1b6f-9334-429e-99e6-f72b4047bee3?version=1.0.

41 Tehdy šlo o cizince s trvalým pobytem a vízem k pobytu nad 90 dnů. Viz Ministerstvo vnitra. Zpráva o situaci v oblasti migrace na územi České republiky v roce 2001, s. 40. [online]. Dostupné z: http:// www.mvcr.cz/clanek/zpravy-o-situaci-v-oblasti-migrace-a-integrace-cizincu-v-ceske-republice-za -roky-2001-2016.aspx. V roce 1990 tvořili cizinci jen 0,3\% obyvatel (usnesení vlády ze dne 8. února 2006 č. 126, III. Aktualizovaná koncepce integrace cizinců, s. 1, pozn. č. 2).

42 Usnesení vlády ze dne 18 . ledna 2016 č. 26, III., kapitola 1. Analýza aktuální situace v oblasti integrace cizinců na území České republiky, s. 8. 
a 29104 jich udělila. Naproti tomu v roce 2016 umožnil systém Visapoint ${ }^{43}$ z Vietnamu podat pouze 551 žádostí o dlouhodobé vízum a 908 žádostí o dlouhodobý pobyt. Podobný posun lze vidět i u Ukrajiny. V roce 2008 byl počet žádostí o dlouhodobé vízum 110772 a 95012 jich bylo uděleno, v roce 2016 umožnil systém Visapoint podat na Ukrajině pouze 2819 žádostí o dlouhodobé vízum a 2504 žádostí o dlouhodobý pobyt.

\section{PŘÍKLADY SELHÁVÁNÍ STÁTU PŘI INTEGRACI CIZINCŮ (UVEDENÝCH V KONCEPCÍCH INTEGRACE)}

\subsection{STESKY MINISTERSTVA VNITRA NA JINÉ RESORTY \\ (VČETNĚ PERSONÁLNÍ NEDOSTATEČNOSTI) ANEB JAK TO CELÉ NEFUNGUJE}

Pravidelně se v různých koncepcích objevují stížnosti ministerstva vnitra, resp. práce a sociálních věcí na jiné resorty, které neplní svoje povinnosti vyplývající $\mathrm{z}$ př́íslušných usnesení vlády $\mathrm{k}$ přijímání integračních opatření. ${ }^{44}$ Tak např. již usnesení vlády ze dne 11. února 2004 č. $129^{45}$ uvádí, že „,[n]ěkteré úkoly usnesení vlády č. 55/2003 nebyly, ani přes koordinační úsilí Ministerstva vnitra, splněny v potřebné kvalitě a ovlivnily zpracování předloženého materiálu do vlády. (...) [N]esplněné úkoly zpomalují realizaci a rozvoj Koncepce ve srovnání s původními plány a cíli."46 Totéž usnesení označuje za jednu z nejvýznamnějších překážek plnění uložených úkolů „,nedostatečné personální a organizační zajištění agendy Koncepce v rámci některých ministerstev. “47 Usnesení vlády ze dne 5. ledna 2005 č. $5^{48}$ (tedy více než pět let po přijetí Zásad a více než 4 roky od schválení první koncepce) konstatuje: „V prvé řadě doposud nedošlo k přesnému vymezení předpokladů integrace, jaké jsou cíle politiky integrace a jakými prostředky lze integrace dosáhnout." Usnesení vlády ze dne 9. února 2011 č. $99^{49}$ kriticky hodnotí odhodlání ministerstev (vyjma koordinátora integrace) v oblasti integrace cizinců: „Za komplikaci účinné realizace Koncepce integrace cizinců lze považovat nedostatečně jasně formulované odhodlání rezortů věnovat se otázkám integrace cizinců. Jednotlivé rezorty zpravidla spoléhají na iniciativu rezortu pověřeného koordinací (ministerstvo vnitra) a ne vždy přebírají odpovědnost za politiku integrace $\mathrm{v}$ rámci vlastního rezortu. Je nezbytné, aby rezorty přistupovaly k realizaci

$43 \mathrm{~V}$ podrobnostech $\mathrm{k}$ tomuto objednávkovému systému srov. POŘÍZEK, P.: Brána nebo zábrana problematické aspekty systému Visapoint. In JÍLEK, D. - POŘíZEK, P. (eds.): Aktuální právní problémy azylového a cizineckého práva. Brno, 2016, s. 11-121.

44 Viz rovněž např. spor mezi MPSV a ministerstvem vnitra ohledně vyčlenění částky na integraci cizinců ze státního rozpočtu na rok 2005 (usnesení vlády ze dne 5. ledna 2005 č. 5, II. Předkládací zpráva, s. 2, 3).

45 K realizaci Koncepce integrace cizinců v roce 2003 a její další rozvoj v souvislosti se vstupem České republiky do Evropské unie, II. Předkládací zpráva.

46 Materiál dále např. zmiňuje, že již v roce 2002 měla MPSV, MŠMT, MZ, MK, MPO a MMR zpracovat Analýzu situace a postavení cizinců a návrh opatření v působnosti ministerstva, $\mathrm{k}$ čemuž došlo až v roce 2003. Dále obsahuje kritiku (nesplnění nezbytných formálních a obsahových požadavků) plánů integračních politik MMR a MK.

47 II. Předkládací zpráva.

48 IV. Postup při realizaci koncepce v roce 2005, s. 15.

49 III., kapitola 1. Analýza aktuální situace v oblasti integrace cizinců na území České republiky, s. 14. 
politiky integrace aktivně, systematicky sledovaly a analyzovaly vývoj a změny situace na poli integrace cizinců $\mathrm{v}$ rámci rezortu a reagovaly zaváděním př́íslušných opatření.“ (důraz převzat)

Jednotlivé koncepce jsou plné konkrétních (legislativních i nelegislativních) úkolů uložených př́slušným ministerstvům a bohužel i jejich nesplnění, popř. odložení. Za všechny zmiňme opatření 1.1.5. z usnesení vlády ze dne 17. března 2008 č. $259,{ }^{50}$ dle něhož bylo MŠMT uloženo do prosince 2007 ,[V]ytvořit metodiku výuky českého jazyka pro cizince, respektující specifika jednotlivých skupin imigranti̊, se zřetelem ke koncepci úvodních kurzů pro cizince a zaslat informaci o splnění úkolu MPSV.“ Důvod nesplnění tohoto úkolu se mi zdá př́značný pro aktivity některých ministerstev na poli integrace cizinců: „Opatření 1.1.5 nemohlo být v roce 2007 naplněno, nebot' v té době nedošlo k dohodě mezi resorty týkající se financování daného úkolu.“"51

\subsection{NEDOSTATEČNÉ ZAPOJENÍ ORGÁNŮ ÚZEMNÍCH SAMOSPRÁV DO INTEGRACE CIZINCŮ}

Zejména v prvním období se koncepce kriticky vyjadřují k zapojení místních/krajských samospráv do integrace cizinců. Usnesení vlády ze dne 11. února 2004 č. 129 konstatuje, že výzva ministra vnitra hejtmanům a starostům obcí s rozšířenou působností ke spolupráci na koncepci „zůstala bez potřebné odezvy.“52 Dále doplňuje, že minimální zájem orgánů územní samosprávy participovat na realizaci koncepce „představuje závažný problém pro zvýšení účinnosti opatření na podporu integrace na místní úrovni a pro př́pravu budoucí decentralizace Koncepce v praxi.“53 Podobný postoj přetrvával i v roce $2004 .{ }^{54}$

Postupně dochází ke změně přístupu samospráv, ke zřizování poradních orgánů pro otázky integrace cizinců v některých krajích i městech a k rozvoji spolupráce samospráv s nevládními organizacemi. Řada problémů však přetrvává. Tak např. usnesení vlády ze dne 17. března 2008 č. $259^{55}$ zmiňuje, že ,[u]rčitým nedostatkem je absence legislativní úpravy, která by upřesnila dělbu kompetencí mezi ústředními orgány státní správy a orgány územní samosprávy, včetně vytvoření podmínek pro utváření regionálních a místních strategií integrace cizinců při zachování jednotné politiky vlády v oblasti integrace cizinců.“ Přes všechna zlepšení analýza integrace cizinců ještě v roce 2011

50 III. Zpráva o realizaci Koncepce integrace cizinců v roce 2007, s. 8.

51 Viz rovněž např. konstatování ve vztahu k plnění úkolu (vyplývajícího z usnesení vlády č. 55 ze dne 13. ledna 2003) zpracovat jednotlivými ministerstvy návrh legislativních a praktických opatření: „Z uvedených ministerstev však materiály zpracovala v požadované kvalitě pouze ministerstva práce a sociálních věcí, školství, mládeže a tělovýchovy a průmyslu a obchodu.“ (usnesení vlády ze dne 5. ledna 2005 č. 5, III. Realizace Koncepce integrace cizinců do konce roku 2004, s. 7).

52 Usnesení vlády ze dne 11. února 2004, III. Realizace koncepce integrace cizinců v roce 2003.

53 Tamtéž, IV. Postup při realizaci Koncepce v roce 2004 a její další rozvoj v souvislosti se vstupem České republiky do Evropské unie.

54 Usnesení vlády ze dne 5. ledna 2005 č. 5, III. Realizace Koncepce integrace cizinců do konce roku 2004, s. 9: „Z odpovědí, které Ministerstvo práce a sociálních věcí obdrželo, vyplývá, že postoje krajů či obcí s rozšírenou působností k problematice integrace cizinců a rozvoje Koncepce se oproti předchozímu roku výrazně nezměnily."

55 III. Zpráva o realizaci Koncepce integrace cizinců v roce 2007, s. 26. 
shrnuje, že „[p]okud jde o integraci na lokální úrovni, až na výjimky si obce zatím nejsou dostatečně vědomy nutnosti reflektovat prrítomnost cizinců ve městě a předcházet potenciálním problémům ve vzájemném soužití. “56 Analýza z roku 2016 sice zmiňuje úspěšnost integračních projektů obcí (dřive emergentních projektů), na straně druhé tyto projekty však realizovalo pouze deset obcí. ${ }^{57}$

Ve všech krajích byla zřízena pozice krajského koordinátora pověřeného integrací cizinců, ,avšak tito koordinátoři zároveň vykonávají řadu dalších agend a nemají potřebný prostor ani kompetence pro plnohodnotný výkon koordinace integrace cizinců v kraji“ “. ${ }^{58}$ Stejná charakteristika činnosti krajských koordinátorů přetrvává i v roce $2016 .{ }^{59}$

\subsection{JEDEN PŘÍKLAD ZA VŠECHNY, JAK SE TO NĚKDY „VLEČE“ (ZAJIŠTĚNÍ BEZPLATNÉ JAZYKOVÉ PŘÍPRAVY DĚTEM Z TŘETÍCH ZEMÍ NA ZÁKLADNÍCH ŠKOLÁCH)}

Již usnesení vlády ze dne 8 . února 2006 č. $126^{60}$ uvádí, že „,[v] oblasti vzdělávání je závažnou překážkou neexistence povinnosti zajistit žákům, kteří jsou státními občany jiných, než členských zemí Evropské unie, bezplatnou př́pravu k jejich začlenění do základního vzdělávání, zahrnující výuku českého jazyka“. Shodně se vyjadřuje zpráva o realizaci koncepce o rok později: „Současná právní úprava př́stupu ke vzdělávání a poskytování školských služeb cizincům ze třetích zemí, obsažená v zákoně č. 561/2004 Sb. (...), nezaručuje všem dětem - cizincům pocházejícím ze zemí mimo členské země EU (...) a oprávněně pobývajícím na území ČR přístup ke vzdělávání a ke školským službám za stejných podmínek jako dětem - občanům ČR a cizincům, kteří mají zvýhodněné postavení, jako jsou občané EU. Tato skutečnost je citlivá, zejména pokud jde o výši úhrad za poskytované služby. V návaznosti na to dochází k řadě negativních jevů (např̀. odhlašování dětí cizinců z mateřských škol, čímž dítě ztrácí jedinečnou možnost integrovat se do majoritní společnosti již v rámci předškolního vzdělávání). Výše uvedený stav je v rozporu se záměry Koncepce integrace cizinců, nebot' stávající systém je svou povahou proti-integrační."61 Ke zlepšení nedošlo ani v roce 2007. ${ }^{62}$ Opakované nesplnění úkolu uloženého MŠMT v této oblasti zmiňuje i Zpráva

56 Usnesení vlády ze dne 9. února 2011 č. 99, III., kapitola 1. Analýza aktuální situace v oblasti integrace cizinců na území České republiky, s. 15.

57 Usnesení vlády ze dne 18. ledna 2016 č. 26 III., kapitola 1. Analýza aktuální situace v oblasti integrace cizinců na území České republiky, s. 11.

58 Usnesení vlády ze dne 9. února 2011 č. 99, III., kapitola 1. Analýza aktuální situace v oblasti integrace cizinců na území České republiky, s. 15.

59 „V krajích je zpravidla zř́zena funkce regionálního koordinátora pověreného také integrací cizinců; tito koordinátoři však zároveň vykonávají řadu dalších agend a nedisponují dostatečnými kompetencemi ani prostorem pro plnohodnotný výkon koordinace integrace cizinců v kraji." Usnesení vlády ze dne 18. ledna 2016 č. 26, III., kapitola 1. Analýza aktuální situace v oblasti integrace cizinců na území České republiky, s. 10.

60 Ke Koncepci integrace cizinců v roce 2005, III. Aktualizovaná koncepce integrace cizinců, s. 28.

61 Usnesení vlády ze dne 21. února 2007 č. 126 ke Zprávě o realizaci Koncepce integrace cizinců v roce 2006, III. Zpráva o realizaci Koncepce integrace cizinců v roce 2006, s. 20.

62 Usnesení vlády ze dne 17. března 2008 č. 259, IV. Postup při realizaci Koncepce integrace cizinců v roce 2008, s. 36: „(a) znalost českého jazyka dětí - cizinců ze třetích zemí: Podpora znalosti češtiny těchto 
o realizaci Koncepce integrace cizinců v roce 2009.63 Usnesení vlády ze dne 9. února 2011 č. $99^{64}$ si na jedné straně všímá toho, že ,[s] celkovým nárůstem počtu cizinců ze třetích zemí pozvolna stoupá i počet žáků a studentů z jejich řad v českých školách. (...) Za posledních 5 let (mezi školními roky 2005/2006 a 2009/2010) se počet studentů/ žáků ze třetích zemí zvýšil o 39,1% (z 20309 na 28 243)“. Na straně druhé je nuceno opět konstatovat nesplnění úkolu uloženého MŠMT: „Zásadním úkolem integrace je zajištění rovných př́ležitostí dětí - cizinců ve vzdělávání. (...) Problémem je však skutečnost, že bezplatná výuka češtiny v rámci základního vzdělávání je v České republice zajištěna pouze dětem ze zemí Evropské unie, ne však žákům-cizincům ze třetích zemí. (...) Praxe, kdy školy řeší situaci zařazováním žáků až o několik ročníků níže než odpovídá jejich věku, je kontraproduktivní a k integraci žáků-cizinců nepřispívá. Enormní jazyková bariéra komplikuje samotnou výuku a vyžaduje mimořádné úsilí ze strany učitelů včetně nezbytnosti individuálního př́stupu. Neznalost češtiny komplikuje rovněž komunikaci mezi rodiči žáků a školou. "65 K nápravě došlo až s účinností od 1. ledna 2012 zákonem č. 472/2011 Sb., který novelizoval § 20 odst. 6 školského zákona (zákon č. 561/2004 Sb.). Trvalo to tedy přinejmenším sedm let, než MŠMT splnilo svůj úkol.

V oblasti vzdělávání dětí cizinců na základních a středních školách však řada problémů přetrvává. Ještě i Analýza aktuální situace v oblasti integrace cizinců na území České republiky z roku $2016^{66}$ zmiňuje, že školy „nejsou vždy připraveny zajistit výuku dětí-cizinců. Roli zde hraje nízké povědomí škol o povinnosti zařazovat děti-cizince do výuky, př́ípadně neochota čelit zvýšené náročnosti při výuce dětí-cizinců. V některých školách ještě přetrvává nepříliš vhodná praxe, kdy žáci-cizinci neznalí češtiny jsou zařazováni až o několik ročníků níže, než odpovídá jejich věku. (...) Určitý problém představují nedostačující kapacity pro prŕípravu pedagogů k výuce dětí-cizinců češtině i zvyšování jejich interkulturních kompetencí. Vyřešena není systémová finanční podpora výuky češtiny a doučování žáků-cizinců na školách.“

žáků je nesystémová, pouze některé školy řeší tento deficit vlastní iniciativou. Z poznatků České školní inspekce vyplývá, že znalost češtiny dětí - cizinců z třetích zemí není na dostačující úrovni. Př́íprava v ČJ k začlenění do základního vzdělávání je zajištěna prostřednictvím rozvojového programu MŠMT, avšak pouze pro žáky - děti osob se státní příslušností zemí EU. Pro žáky - cizince ze třetích zemí (tedy zemí mimo EU) však systémově zajištěna není.“

63 Usnesení vlády ze dne 22. března 2010 č. 224, III. Zpráva o realizaci Koncepce integrace cizinců v roce 2009, s. 27: „Zajištění bezplatné výuky češtiny v základním vzdělávání také pro děti z třetích zemí: MŠMT bylo usnesením vlády opakovaně uloženo provést legislativní opatření k zajištění bezplatné př́pravy v českém jazyce i pro děti-cizince z třetích zemí. Úkol dosud nebyl splněn. Bezplatná výuka češtiny na základních školách je doposud zajištěna pouze pro děti z EU, nikoli pro děti z třetích zemí (mimo EU).“

64 III., kapitola 1. Analýza aktuální situace v oblasti integrace cizinců na území České republiky, s. 9.

65 Tamtéž, III., Část 2. Analýza problémů v oblasti integrace cizinců, s. 12. V témže dokumentu (III., kapitola 3. Postup při realizaci aktualizované Koncepce integrace cizinců - Společné soužití v roce 2011, s. 24) se dále uvádí: „Nedostatečná znalost českého jazyka limituje školní prospěch dětí-cizinců ze tř̌etích zemí a v důsledku je znevýhodňuje v možnosti dalšího vzdělávání, získání zaměstnání a kariérního růstu. Bezplatná výuka českého jazyka je zajištěna pouze pro děti cizinců ze zemí Evropské unie. Ministerstvu školství mládeže a tělovýchovy (MŠMT) bylo proto již v minulém období uloženo legislativním opatřením systémově zajistit výuku češtiny pro žáky - cizince ze třetích zemí, a dále zajistit rozšíření statutu žáka se speciálními vzdělávacími potřebami i na dítě - cizince ze třetích zemí, které má problémy s češtinou jako cizím jazykem."

66 Usnesení vlády ze dne 18. ledna 2016 č. 26 o aktualizované Koncepci integrace cizinců - Ve vzájemném respektu a o Postupu při realizaci aktualizované Koncepce integrace cizinců v roce 2016, III., kapitola 1, s. 12. 
Ochránkyně aktuálně řeší např. problematiku zhoršení postavení žáků s odlišným mateřským jazykem (dále jen „OMJ“) v jejich př́istupu k podpůrným opatřením podle § 16 školského zákona, $k$ níž došlo od záríi 2016 po přijetí zákona č. 82/2015 Sb. ${ }^{67}$ Ochránkyně se dále zabývá právní úpravou skládání společné části maturitní zkoušky z českého jazyka pro žáky s OMJ. ${ }^{68}$ Tato kategorie studentů čelí rovněž problémům při skládání jednotné príijímací zkoušky z českého jazyka na střední školy. ${ }^{69}$

\section{4 ÚČAST VYBRANÝCH KATEGORIÍ CIZINCŮ (ZEJMÉNA DĚTÍ) NA VEŘEJNÉM ZDRAVOTNÍM POJIŠTĚNÍ}

Jednotlivé koncepce dlouhodobě připomínají, že jednu z překážek sociálně-ekonomické integrace představuje fakt, že některé kategorie cizinců nemají př́stup do veřejného zdravotního pojišš̌ní. ${ }^{70}$ Ten je garantován až cizincům s trvalým pobytem a cizincům, kteří jsou v ČR zaměstnáni. Jejich rodinným př́slušníkům, včetně dětí, kteří v České republice pobývají na dlouhodobý pobyt za účelem sloučení rodiny, je však vstup do veřejného zdravotního pojištění upřen. Již v roce 2004 analýza situace a postavení cizinců dlouhodobě žijících na území České republiky upozorňuje na nevýhody smluvního zdravotního pojištění a požaduje zahrnutí dlouhodobě pobývajících dětí (tehdy na vízum $\mathrm{k}$ pobytu nad 90 dnů) do veřejného zdravotního pojištění. ${ }^{71}$ Ak-

67 Šetření ochránkyně v této věci je vedeno pod sp. zn. 1345/2017/VOP/BKU. Ochránkyně kritizuje výklad, dle něhož MŠMT nevnímá neznalost či nedostatečnou znalost vyučovacího jazyka jako dostatečnou speciální vzdělávací potřebu zakládající nárok na poskytnutí odpovídajícího podpưrného opatření.

68 Setření vedené pod sp. zn. 11/2017/SZD. Dle ochránkyně není zřejmé, zda dílčí úleva poskytovaná př̀i konání maturitní zkoušky pouze některým žákům s OMJ (těm, kteří na území České republiky nepobývají déle než čtyři roky) odpovídá možnostem a jazykovým kompetencím žáků s OMJ. Pokud neuspějí u maturitní zkoušky, neukončí úspěšně své středoškolské vzdělání, což zásadně omezuje jejich šance na pracovním trhu a na úspěšnou integraci do společnosti.

69 Dle ochránkyně je právní úprava ve vztahu k žákủm s OMJ velmi př́ísná, když o prominutí konání zkoušky nemohou požádat ti žáci s OMJ, kteří získali jakkoli krátké předchozí vzdělání na škole v České republice. Musí tuto zkoušku konat na stejné úrovni jako rodilí mluvčí, a to bez ohledu na jejich úroveň znalosti českého jazyka. Možnosti uzpůsobení podmínek konání této zkoušky pro žáky se speciálními vzdělávacími potřebami konkrétně pro žáky s OMJ nezohledňují jejich specifickou situaci a prakticky umožňují pouze zvýšení časového limitu. V podrobnostech lze odkázat i na prezentace z kulatého stolu Žáci s odlišným mateřským jazykem a zkoušky z ČJ - překážka v přístupu ke střednímu vzdělávání?, který se uskutečnil dne 21.11.2017 v Kanceláŕi veřejného ochránce práv (dostupné z: https://www.ochrance.cz/dalsi-aktivity/archiv -vzdelavacich-akci/?tx_odcalendar\%5Buid\%5D=251\&cHash=325b3fc07a566fld7cd9684bfb47b73b).

70 Viz např. usnesení vlády ze dne 8. února 2006 č. 126, III. Aktualizovaná koncepce integrace cizinců, s. 28: „Jako hlavní překážky v oblasti sociálně-ekonomické integrace byly identifikovány (...) nemožnost podílet se na veřejném systému zdravotního pojiššění u státních občanů třetích zemí nebo jejich rodinných př́slušníků (zejména dětí), kteří nejsou zaměstnanci na území ČR, nebo nemají na území ĆR trvalý pobyt, nebo se jedná o občany státu, se kterým nemá ČR uzavřenou bilaterální smlouvu (nejčastěji smlouvu o sociálním zabezpečení), nebo se na tyto osoby nevztahuje Nařízení Rady (ES) č. 859/2003, které rozšiřuje používání ustanovení nařízení (EHS) č. 1408/71 a Nařízení č. 574/72 na státní občany třetích zemí.“

71 Usnesení vlády ze dne 11. února 2004 č. 129, př́loha č. 1: „Smluvní zdravotní pojištění je nákladné a přináší s sebou i další nevýhody - určité druhy zdravotní péče (zejména péče poskytovaná osobám s vrozenou vadou, některými chronickými onemocněními, cukrovkou léčenou inzulínem apod.) se $\mathrm{z}$ prostředků tohoto pojištění nehradí. V souvislosti s naléhavou potřebou vyř̌šit tento problém príijala vláda ČR usnesení č. 546/2001. V souladu s tímto usnesením a Úmluvou o právech dítěte připravilo MZdr. návrh Zákona o dětech cizinců, které dlouhodobě pobývají na území ČR (...), který byl v dubnu 2003 předložen k projednání vládě ČR. Navrhovaný zákon upravuje zdravotní pojištění o nezaopatř̌ené děti cizinců mladší 18 ti let, které pobývají na území ČR na základě víza k pobytu nad 90 dnů. Zdravotní 
tualizovaná koncepce integrace cizinců, ${ }^{72}$ která tvoří př́ílohu III. usnesení vlády ze dne 8. února 2006 č. 126, ukládá ministerstvu zdravotnictví předložit do konce roku 2006 legislativní návrh, který by umožnil děti cizinců a cizince - podnikatele zahrnout do veřejného zdravotního pojištění. Tento úkol splněn nebyl, proto se znovu objevuje v usnesení vlády ze dne 17. března 2008 č. $259 .{ }^{73}$ Popsaná situace přetrvává i v roce $2009^{74}$ a $2010^{75}$, a nepodařilo se ji vyřešit až do současnosti. Zároveň v mezidobí došlo k upuštění od striktního požadavku na začlenění uvedených kategorií cizinců do veřejného zdravotního pojištění. ${ }^{76}$

Tento stav je dlouhodobě předmětem kritiky veřejného ochránce práv, ${ }^{77}$ Rady vlády pro lidská práva, ${ }^{78}$ mezinárodních kontrolních mechanizmư ${ }^{79}$ a nejnověji i Nejvyššího soudu. Ten ve svém rozsudku sp. zn. 33 Cdo 2039/2015 ze dne 22. záŕí 2016, týkajícím se problematiky tzv. nepojistitelných dětí cizinců, uvedl: „Je zřejmé, že ani po mnohaletém úsilí se zatím v českém právním řádu nepodařilo odstranit dichotomii mezi „ideálním“ stavem předjímaným v každoročně aktualizovaných koncepcích integrace cizinců, jehož dosažení vláda ve svých četných usneseních (dovolací soud odkazuje jen na nejvýznamnější z nich) ukládala ministerstvu zdravotnictví ve spolupráci s mi-

pojištění zákonně vymezeného okruhu dětí je podle návrhu zahrnuto do veřejného zdravotního pojištění a tyto děti by tak měly mít $\mathrm{v}$ obecné rovině postavení pojištěnců veřejného zdravotního pojištění podle zákona č. 48/1997 Sb.“

72 Tamtéž, s. 36.

73 III. Zpráva o realizaci Koncepce integrace cizinců v roce 2007, s. 10.

74 Usnesení vlády ze dne 22. března 2010 č. 224, III. Zpráva o realizaci Koncepce integrace cizinců v roce 2009, s. 20.

75 Usnesení vlády ze dne 9. února 2011 č. 99, III., kapitola 3. Postup při realizaci aktualizované Koncepce integrace cizinců - Společné soužití v roce 2011, s. 29.

76 Srov. např. usnesení vlády ze dne 18. ledna 2016 č. 26, III., kapitola 1. Analýza aktuální situace v oblasti integrace cizinců na území České republiky, s. 14.

77 Viz např́íklad tiskové zprávy ochránce z 11. března 2009 Nerovné postavení cizinců v ČR v přístupu k veřejnému zdravotnímu pojištění (dostupné z: https://www.ochrance.cz/aktualne/tiskove-zpravy-2009 /nerovne-postaveni-cizincu-v-cr-v-pristupu-k-verejnemu-zdravotnimu-pojisteni/), z 23. července 2014 Navrhovaný zákon o zdravotním pojištění cizinců je špatný a straní pojišt’ovnám (dostupné z: https://www .ochrance.cz/aktualne/tiskove-zpravy-2018/navrhovany-zakon-o-zdravotnim-pojisteni-cizincu-je-spatny -a-strani-pojistovnam/) a z 21. července 2010 Nerovné postavení cizinců nemusí být diskriminací, přesto vyžaduje řešení (dostupné z: https://www.ochrance.cz/aktualne/tiskove-zpravy-2013/nerovne-postaveni -cizincu-nemusi-byt-diskriminaci-presto-vyzaduje-reseni/).

78 Viz usnesení Rady vlády ČR pro lidská práva ze dne 26. 2. 2009 k začlenění vybraných kategorií cizinců, kteři pobývají v České republice přechodně, do systému veřejného zdravotního pojištění.

79 Výbor OSN pro práva dítěte v Závěrečných doporučeních pro Českou republiku ze dne 4. 8. 2011 vyjádřil znepokojení nad tím, že děti cizích státních příslušníků nemají přístup k veřejnému zdravotnímu pojištění a jsou povinny zajistit si soukromé zdravotní pojištění s nepoměrně vyššími náklady (čl. 53 a 54 Závěrečných doporučení). Výbor OSN pro hospodářská, sociální a kulturní práva v Závěrečných doporučeních pro Českou republiku ze dne 23. 6. 2014 vyjádřil v obecné rovině znepokojení nad tím, že migranti bez povolení k trvalému pobytu, včetně osob odkázaných na migranty s trvalým pobytem, nejsou zahrnuti do státního systému zdravotního pojištění. Upozornil na př́pady, kdy některým migrantům je odepřen přístup ke zdravotní péči v režimu soukromého zdravotního pojištění, a uvedl, že tento stav je v rozporu s Mezinárodním paktem OSN o hospodářských, sociálních a kulturních právech a v rozporu se zákonem č. 198/2009 Sb., o rovném zacházení a o právních prostředcích ochrany před diskriminací a o změně některých zákonů (antidiskriminační zákon; čl. 15 Závěrečných doporučení). Rovněž Výbor OSN pro odstranění všech forem diskriminace žen v Závěrečných doporučeních pro Českou republiku ze dne 10. 11. 2010 kritizoval vyloučení žen, které na území České republiky nemají trvalý pobyt, a jejich dětí ze systému veřejného zdravotního pojištění a poskytování zdravotnických služeb (čl. 32 a 33 Závěrečných doporučení) - převzato z rozsudku Nejvyššího soudu, sp. zn. 33 Cdo 2039/2015 ze dne 22. zář́i 2016. 
nisterstvem vnitra, a realitou. $V$ konečném důsledku tak nadále dochází $\mathrm{k}$ nerovnosti v př́stupu ke zdravotní péči a diskriminaci určité skupiny dětí v rozporu s čl. 24 odst. 1 Úmluvy o právech dítěte." 80 Jen velmi těsnou většinou 8:7 hlasům prošel testem ústavnosti stávající rozsah veřejného zdravotního pojištění ve vztahu k cizincům u Ústavního soudu (viz nález Pl. ÚS 2/15 ze dne 3. května 2017).

\section{5 ÚČAST CIZINCŮ VE VOLBÁCH DO MÍSTNÍCH ZASTUPITELSTEV}

Umožnit cizincům s trvalým pobytem volit ve volbách do místních zastupitelstev představuje další z nesplněných slibů koncepcí integrace, který byl navíc postupně opuštěn. ${ }^{81}$ Již Analýza situace a postavení cizinců dlouhodobě žijících na území České republiky v roce $2004^{82}$ uváděla, že ,[j]ednou z priorit nejbližšího období by proto mělo být rozšíření forem účasti cizinců na veřejném životě ve smyslu Úmluvy RE o účasti cizinců na veřejném životě na místní úrovni z roku 1992, tj. jak prostřednictvím účasti cizinců na místních volbách, tak př́padně i formou zřizování poradních orgánů pro zastoupení cizinců. (...) Možnost širší účasti na politickém a veřejném životě těmito zvláštními formami by pritom mohla být účelně ,spojena's některou z vyšších forem pobytového statusu. Tím by byla vyjádřena i skutečnost, že integrace je mnohostranný proces, který má i politickou dimenzi." 83 Usnesení vlády ze dne 8 . února 2006 č. $126^{84}$ jako hlavní překážky v oblasti politické integrace identifikovalo existenci „povolovacího režimu při vzniku organizací cizích státních př́slušníků a podmínky registrace občanských sdruženi“ a neexistenci „volebního práva cizinců s trvalým pobytem ve volbách do zastupitelstev obcí a krajư“. Ještě usnesení vlády ze dne 9 . února 2011 č. $99^{85}$ zmiňuje, že ,[u]rčité skupiny cizinců pocit'ují skutečnost, že se nemohou zapojit do voleb, jako problém“. Bohužel vláda ${ }^{86}$ i parlament odmítli přiznat volební právo v obecních volbách cizincům s trvalým pobytem v souvislosti s ratifikací Úmluvy Rady Evropy (č. 144) o účasti cizinců na veřejném životě na místní úrovni. ${ }^{87}$ Pro umožnění aktivního volebního práva cizincům s trvalým pobytem ve volbách do místních zastupitelstev se vyjádřila Rada vlády pro lidská práva ${ }^{88}$ i veřejný ochránce práv. ${ }^{89}$

$80 \mathrm{~V}$ odůvodnění rozsudku je podrobně popsána geneze dané problematiky včetně odkazů na různé zdroje (zprávy), které se kriticky vyjadřují k deficitu právní úpravy zdravotního pojištění dětí občanů třetích zemí.

81 Viz např. usnesení vlády ze dne 14 . ledna 2015 č. 20 k postupu při realizaci aktualizované Koncepce integrace cizinců - Společné soužití v roce 2015, II. Předkládací zpráva, s. 5, 6 a III. Postup při realizaci aktualizované Koncepce integrace cizinců - Společné soužití v roce 2015, s. 18; usnesení vlády ze dne 18. ledna 2016 č. 26, III., kapitola 1. Analýza aktuální situace v oblasti integrace cizinců na území České republiky, s. 13.

82 Usnesení vlády ze dne 11. února 2004 č. 129, př́loha č. 1.

83 Dokument explicitně požaduje ,[r]ozšířit možnost účasti cizinců na veřejném a politickém životě, a to zejména vytvořením právních podmínek pro účast dlouhodobě usedlých cizinců ve volbách do zastupitelstev obcí“.

84 III. Aktualizovaná koncepce integrace cizinců, s. 29.

85 III., kapitola 2. Aktualizovaná Koncepce integrace cizinců - Společné soužití, s. 21.

86 Viz usnesení č. 999 z 1. 12. 2014.

87 Úmluva byla ratifikována v rozsahu její kapitoly A, avšak s výhradou bodů B a C.

88 Viz usnesení Rady vlády ČR pro lidská práva ze dne 26. listopadu 2014 k podnětu Výboru pro práva cizinců $\mathrm{k}$ účasti cizinců na veřejném a politickém životě.

89 Viz např. Připomínky ochránce k věcnému záměru volebního zákoníku ze dne 2. února 2011 (dostupné z: https:/www.ochrance.cz/aktualne/tiskove-zpravy-2011/pripominky-ochrance-k-vecnemu-zameru -volebniho-zakoniku/). 
Ochránkyně opakovaně upozornila na skutečnost, že neumožnění výkonu aktivního volebního práva vůči občanům EU s přechodným pobytem porušuje unijní právo. Zákon č. 491/2001 Sb., o volbách do zastupitelstev obcí, ve znění pozdějších předpisů, přiznává aktivní volební právo pouze těm občanům jiných členských států Evropské unie, kteří mají na území České republiky povolen trvalý pobyt. V souladu se Smlouvou o fungování Evropské unie ${ }^{90}$ a směrnicí Rady 94/80/ES ${ }^{91}$ nicméně toto právo náleží rovněž občanům jiných členských států Evropské unie s přechodným pobytem na území České republiky. Na tento nesoulad ochránkyně upozornila již v roce 201492 a dovodila, že jej lze zhojit použitím přímého účinku práva Evropské unie. To následně potvrdil i Krajský soud v Brně ${ }^{93}$ a Krajský soud v Praze ${ }^{94}$ na základě žalob několika občanů Evropské unie s přechodným pobytem podaných před volbami do zastupitelstev obcí v ř́ijnu 2014. Ministerstvo vnitra následně přijalo opatření, jímž umožnilo uplatnění aktivního volebního práva v obecních volbách v říjnu 2014 všem občanům Evropské unie s potvrzením o přechodném pobytu na území České republiky. ${ }^{95}$ Zároveň ministerstvo vnitra přislíbilo ošetřit popsaný nedostatek legislativně novelizací zákona o volbách do místních zastupitelstev, což se však do dnešního dne nepodařilo.

Právně nevyjasněná zůstává i otázka členství občanů EU v politických stranách. Evropská komise $\mathrm{v}$ této věci zahájila s Českou republikou řízení o porušení unijního práva pod č. 2012/2115.

\section{SPOLUPRÁCE S NEVLÁDNÍMI ORGANIZACEMI NA INTEGRACI CIZINCŮ}

V koncepcích je pravidelně zdůrazňována významná role nevládního sektoru na realizaci integrace cizinců. Zároveň se ovšem dlouhodobě nedaří zajistit kontinuitu jejich financování a zmíněna je rovněž nízká informovanost o službách poskytovaných cizincům nevládními organizacemi. Analýza aktuální situace v oblasti integrace cizinců na území České republiky z roku $2011^{96}$ uvádí: „Mezi další problémy

90 Čl. 20 odst. 2 písm. b) a čl. 22 Smlouvy o fungování Evropské unie.

91 Směrnice Rady 94/80/ES ze dne 19. prosince 1994, kterou se stanoví pravidla pro výkon práva volit a práva být volen $\mathrm{v}$ obecních volbách pro občany Unie s bydlištěm v členském státě, jehož nejsou státními př́slušníky.

92 Občané EU žijící v ČR mají právo účastnit se politického života, 23. července 2014 (dostupné z: https:// www.ochrance.cz/aktualne/tiskove-zpravy-2014/obcane-eu-zijici-v-cr-maji-pravo-ucastnit-se-politickeho -zivota/) a Euroobčané, máte právo účastnit se komunálních voleb, 8. zárí 2014 (dostupné z: https://www .ochrance.cz/aktualne/tiskove-zpravy-2014/euroobcane-mate-pravo-ucastnit-se-komunalnich-voleb/).

93 Usnesení Krajského soudu v Brně ze dne 19. zář́i 2014, sp. zn. 64 A 6/2014.

94 Usnesení Krajského soudu v Praze ze dne 22. záŕí 2014, sp. zn. 50 A 21/2014.

95 Občané EU s přechodným pobytem v ČR mohou volit v komunálních volbách, 22. záŕí 2014 (dostupné z: https://www.ochrance.cz/aktualne/tiskove-zpravy-2014/obcane-eu-s-prechodnym-pobytem-v-cr-mohou -volit-v-komunalnich-volbach/).

${ }_{96}$ Usnesení vlády ze dne 9. února 2011 č. 99, III., kapitola 1., s. 15. 
identifikované v souvislosti s působením nevládního sektoru patří nízká aktivita ve vyhledávání a oslovování cizinců. Většina organizací informuje o své nabídce prostřednictvím letáků a internetu nebo navazuje kontakty prostřednictvím dosavadních klientů. To se však ukazuje jako ne zcela dostačující. Lze tak soudit z toho, že značné množství cizinců doposud nemá povědomí o možnosti využít služeb nevládních organizací. (...) Účinnost integračních opatření snižuje opožděné udělování dotací ze státních prostředků. Pravidlem bývá, že subjekty se o jejich rozdělení dozvídají nejdříve ve druhém čtvrtletí a často dochází i k situacím, kdy jsou finance vypláceny až v poslední třetině roku. Ohrožena je tak nejen plynulá návaznost projektů a schopnost realizátorů udržet kvalifikovaný personál, ale především efektivita vynakládaných prostředků.“ O šest let později Analýza aktuální situace v oblasti integrace cizinců97 poznamenává: „S propadem financování ze strany EU fondů, ale i se zpožděním poskytování dotačních prostředků jak z tohoto fondu, tak zdrojů Evropského sociálního fondu, se potýkají také nestátní neziskové organizace NNO. Je nezbytné hledat řešení této situace, která může vést ke snížení kvality i kontinuity služeb poskytovaných NNO v oblasti integrace cizinců."“

\section{PRÁVNÍ JISTOTA POBYTU CIZINCŮ NA ÚZEMÍ ČR / JEJICH INFORMOVANOST / ZÁVISLOST NA ZPROSTŘEDKOVATELÍCH}

Jde o oblasti, v nichž se doposud podařilo dosáhnout jen dílčího pokroku. Zákon o pobytu cizinců byl od roku 2000 novelizován (pokud správně počítám) 51× (!), což vychází čistě matematicky na cca 3 novelizace ročně (!). V zákoně má problém se vyznat zkušený profesionál - právník, který s touto normou pracuje mnoho let, natožpak cizinec bez právnického vzdělání. Norma je nepřehledná, složitá, kazuistická, ${ }^{98} \mathrm{v}$ řadě př́padů s odkazy na postup dle jiných ustanovení zákona. ${ }^{99}$ Tento fakt přispívá $\mathrm{k}$ závislosti cizinců na tzv. zprostředkovatelích (klientech), kteří cizincům za nemalé peníze a často nekvalitně a $\mathrm{k}$ jejich škodě zařizují pobytové záležitosti jak na území, tak při snaze o získání víza či dlouhodobého pobytu ke vstupu na území. V posledně uvedeném př́ípadě tento fenomén souvisel s nefunkčností systému Visapoint v některých migračně exponovaných zemích, ${ }^{100}$ který byl zrušen až k 31. ř́íjnu 2017. Přestože uvedené fenomény koncepce poměrně otevřeně popisují, ke zlepšení nedošlo.

\footnotetext{
${ }^{97}$ Usnesení vlády ze dne 18. ledna 2016 č. 26, III., kapitola 1, s. 11.

${ }^{98}$ Následující opatření, obsažené v Aktualizované Koncepci integrace cizinců - Společné soužití (usnesení vlády ze dne 9. února 2011 č. 99, III., kapitola 2, s. 20), se tak nepodařilo realizovat: „V kontextu posílení informovanosti cizinců bude v nové právní úpravě vstupu a pobytu cizinců usilováno o větší transparentnost pobytu cizinců a zjednodušení podmínek jejich pobytu, což cizincům umožní lepší orientaci v povinnostech spojených s jejich pobytovým statusem.“

${ }^{99}$ Viz POŘÍZEK, P.: Výklad výhrady veřejného pořádku v jednotlivých ustanoveních zákona o pobytu cizinců. In JÍLEK, D. - POŘİZK, P. (eds.): Ročenka uprchlického a cizineckého práva 2016. Brno, 2017, s. 108 , pozn. č. 3 .

${ }^{100}$ V podrobnostech viz POŘÍZEK, P.: Brána nebo zábrana - problematické aspekty systému Visapoint. In JÍLEK, D. - POŘÍZEK, P. (eds.): Aktuální právní problémy azylového a cizineckého práva. Brno, 2016, s. $11-121$.
} 
Již usnesení vlády ze dne 8 . února 2006 č. 126 ke Koncepci integrace cizinců v roce 2005 uvádí: „Základem efektivity podpůrných opatření je řádné fungování stávajících systémů a využití stávajících institucí a instrumentů. Svou funkci mohou právní normy plnit pouze v prrípadě, že jsou adresátưm srozumitelné a dostatečně stabilní a jejich naplňování je účinně vymáháno; v opačném případě působí desintegračně. (...) Provedené analýzy poukázaly na nevyhovující právní úpravu pobytových otázek, která je př́liš komplikovaná a klade na cizince množství formálních požadavků. Nedostatky byly konstatovány též v rovině postupu př́slušných správních úřadů (selhávání při informování cizinců, nízká standardizace požadavků na jednotlivých pracovišstích, korupce, nedostatečná jazyková vybavenost, neprofesionální vystupování).“101

Zprostředkovatelský (klientský) systém má negativní dopady i do pracovního vykořist’ování cizinců: „Významným faktorem, který je důsledkem nedostatečné integrace cizinců a který má i svá nepominutelná bezpečnostní rizika, je pracovní vykořist’ování cizinců v ČR a existence tzv. klientského systému. Toto vykořist'ování může zahrnovat mnoho různých stupňů a forem. Někteří ekonomičtí migranti jsou nuceni snášet jisté formy hrubého zacházení od svých zaměstnavatelů, které může zahrnovat verbální či fyzické násilí či porušení smlouvy, kterou se řídí jejich pracovní vztah. Typickou situací je zadržování výplat či odmítnutí poskytnutí řádného času na odpočinek. Ještě menší skupina osob se cítí být zneužívána takovým způsobem, který lze nazvat otroctvím či nucenou prací. Pracovní vykořist'ování cizinců není okrajovým fenoménem, naopak se jedná o jev, který je běžnou součástí migrační reality v ČR. Skupina zprostředkovatelů zajišt'uje práci klientům za úplatu a zajištuje kontakt s českými zaměstnavateli. Součástí zprostředkování jsou různé typy závazků. Zprostředkování práce je časově a prostorově podmíněným jevem, který vysoce koreluje s nelegální prací. Jedná se o vnitřně diverzifikovaný a složitý jev, který je ovlivněn etnicky.“102

V roce 2016 není situace o moc lepší: „Určitý počet cizinců stále ještě dává před osobním vyřizováním svých záležitostí spojených s pobytem či zaměstnáním přednost zprostředkovatelům (tzv. klientům), nejčastěji osobám z vlastní komunity, které jsou ochotny vyř́́dit jim věc tzv. na klíč, nikoli však nezištně a ne vždy v souladu s legálními postupy. $\mathrm{V}$ důsledku této praxe se cizinci často stávají obětí manipulace. I přes jisté snížení role zprostředkovatelů v poslední dekádě je nezbytné cizince motivovat k samostatnému vyřizování jejich záležitostí.“103

\section{ZNALOST ČESKÉHO JAZYKA}

Znalost českého jazyka je koncepcemi opakovaně vzpomínána jako zásadní předpoklad úspěšné integrace cizinců do majoritní společnosti. ${ }^{104}$ Ale i v této oblasti

\footnotetext{
${ }^{101}$ III. Aktualizovaná koncepce integrace cizinců, s. 27.

102 Usnesení vlády ze dne 21. února 2007 č. 126, příloha č. 2, Bezpečnostní aspekty integrace cizinců, s. 6.

103 Usnesení vlády ze dne 18. ledna 2016 č. 26, III., kapitola 1. Analýza aktuální situace v oblasti integrace cizinců na území České republiky, s. 11.

104 Viz např. usnesení vlády ze dne 9. února 2011 č. 99, III., kapitola 2. Aktualizovaná Koncepce integrace cizinců - Společné soužití, s. 19: „Znalost českého jazyka má zásadní význam pro začlenění cizinců do
} 
přes nepochybný pokrok přetrvávají závažné nedostatky. Ještě v roce 2016 Analýza aktuální situace v oblasti integrace cizinců na území České republiky uvádí: „Kurzy češtiny pro dospělé poskytují všechna regionální Centra na podporu integrace cizinců i řada nestátních neziskových organizací. Jedná se zpravidla o kurzy bezplatné, príípadně kurzy se zálohou vratnou po absolvování kurzu. V některých regionech zájem o kurzy češtiny stagnuje, naopak v hl. m. Praze (kde žije téměř polovina cizinců na území ČR) zájem cizinců o návštěvu jazykových kurzů vysoce přesahuje nabídku. Problémem jsou obtíže cizinců týkající se sladění jazykového vzdělávání a rodinného a pracovního života, a také řádné dokončení jejich účasti na kurzu. Je naprosto nezbytné výrazně posílit kapacitu kurzů češtiny pro dospělé na všech úrovních pokročilosti, zajistit jejich kvalifikovanou úroveň, možnost návaznosti jednotlivých kurzů dle úrovně znalostí češtiny a nabídku nástrojů pro samostudium češtiny. “105 Přitom znalost češtiny jako nezbytného předpokladu úspěšné integrace je zdůrazňována i samotnými cizinci. Za bariéru integrace považuje její neznalost, resp. pouze limitovanou znalost $59 \%$ cizinců s přechodným pobytem, ale i $48 \%$ cizinců s trvalým pobytem. ${ }^{106}$

\section{ZAMĚSTNANOST CIZINCŮ A ČERPÁNÍ SOCIÁLNÍCH DÁVEK (EKONOMICKÁ SOBĚSTAČNOST)}

V oblasti ekonomické a sociální soběstačnosti statistiky prokazují, že cizinci se integrují úspěšně. Na jedné straně ještě v roce 2006 Aktualizovaná koncepce integrace cizinců konstatuje: „Podle současné právní úpravy není cizinec (nezískal-li trvalý pobyt) ani po dvaceti letech nepřetržitého zaměstnávání v ČR oprávněn ke změně zaměstnavatele, dokonce ani ke změně profese $v$ rámci jednoho zaměstnavatele a jeho povolení k zaměstnání musí být každoročně prodlužováno či obnovováno. To je zdrojem vysoké míry právní nejistoty cizince, která působí protiintegračně. “"107 Na straně druhé koncepce setrvale potvrzují, že nezaměstnanost cizinců a čerpání sociálních dávek jsou zanedbatelné. Analýza z roku 2011 uvádí: „I přes poměrně vysoký počet cizinců ze třetích zemí v produktivním věku, kteří nejsou výdělečně činní, je počet cizinců ze třetích zemí evidovaných na úr̆adech práce mezi uchazeči o zaměstnání velmi nízký. K 31. prosinci 2009 bylo na úřadech práce evidováno 4523 těchto osob, z nich pak méně než třetina (1319 osob) pobírala podporu v nezaměstnanosti. (...) Rovněž na čerpání sociálních dávek se cizinci ze třetích zemí podílejí minimálně. V roce 2009 jejich podíl na celkovém počtu dávek dosáhl pouze $0,6 \%$ (10 775 dávek).“108 Situace

společnosti a představuje hlavní předpoklad úspěšné integrace. Do budoucna proto bude kladen důraz na: - zajištění co nejširší dostupnosti výuky češtiny ve všech fázích pobytu cizince.“

${ }^{105}$ Usnesení vlády ze dne 18. ledna 2016 č. 26, III., kapitola 1, s. 13.

${ }^{106}$ SCHEBELLE, D. - KUBÁT, J. - KOTÍKOVÁ, J. - VYCHOVÁ, H.: Průzkum veřejného mínění cizinců z třetích zemí o otázkách integrace a jejich náhledů na majoritni společnost a život v ní. Praha, 2015 [online]. Dostupné z: http://cizinci.cz/repository/2575/file/Pr\%C5\%AFzkum\%20ve\%C5\%99ejn\%C3\%A9ho\%20m \%C3\%ADn\%C4\%9Bn\%C3\%AD\%20cizinc\%C5\%AF\%20(2015).pdf.

107 Usnesení vlády ze dne 8 . února 2006 č. 126, III., s. 22, pozn. č. 43. Popsaný stav se naštěstí podařilo v mezidobí napravit zejména v souvislosti s přijímáním unijní legislativy v této oblasti.

${ }^{108}$ Usnesení vlády ze dne 9 . února 2011 č. 99, III., kapitola 1. Analýza aktuální situace v oblasti integrace cizinců na území České republiky, s. 9. 
je podobná i v roce 2015: „Počet cizinců ze třetích zemí evidovaných na úřadech práce mezi uchazeči o zaměstnání je velmi nízký. K 30. červnu 2015 bylo na úřadech práce evidováno 5977 těchto osob, z nich pak necelých 17 \% (1010 osob) pobíralo podporu v nezaměstnanosti. (...) Rovněž na čerpání sociálních dávek se cizinci ze třetích zemí podílejí minimálně. V červnu 2015 jejich podíl na celkovém počtu dávek dosáhl pouze $1,2 \%$ (19,1 tis. dávek). "109 Obdobně k červnu 2016 činil podíl cizinců ze třetích zemí na celkovém objemu čerpání sociálních dávek pouhá $1,3 \%$. ${ }^{110}$ Stejná situace přetrvávala i v červnu 2017.111

\section{BEZPEČNOSTNÍ ASPEKTY (TRESTNÁ ČINNOST CIZINCŮ)}

Pokud jde o bezpečnostní aspekty př́tomnosti cizinců na území ČR, veřejně dostupné dokumenty neobsahují žádné informace o tom, že by cílová skupina integrace představovala jakoukoli výraznější hrozbu pro bezpečnost státu. Usnesení vlády ze dne 11. února 2004 č. $129^{112}$ uvádí: „Celkově lze konstatovat, že bezpečnostní rizika plynoucí $\mathrm{z}$ integrace cizinců jsou $\mathrm{v}$ současné době relativně malá a oproti minulému hodnocenému období nedošlo k výraznějším posunům. “ Obdobné hodnocení obsahuje i zpráva o realizaci koncepce integrace cizinců v roce 2007. ${ }^{113}$ Vládní dokument Strategie migrační politiky z roku $2015^{114}$ konstatuje: „Integrace cizinců je zásadním nástrojem úspěšné migrační politiky. Jedná se o obousměrný proces, do kterého vstupují jak cizinci, tak majoritní společnost. V tomto ohledu Česká republika disponuje vyváženou integrační politikou, která je dlouhodobě neproblematickou oblastí.“

Dlouhodobě nepředstavuje závažnější problém ani trestná činnost cizinců. Tak např., dle usnesení vlády ze dne 11. února 2004 č. $129^{115}$ došlo „,[v] roce 2002 (...) ke stagnaci kriminality cílové skupiny, podíl stíhaných cizinců s dlouhodobým pobytem, trvalým pobytem či těch, kteří v České republice získali azyl, tvoří $1,3 \%$ z celkem stíhaných osob v České republice, stejně jako v roce 2001." Ve Zprávě o realizaci Koncepce integrace cizinců v roce $2006^{116}$ se lze dočíst: „Zastoupení cizinců mezi trestně stíhanými osobami v České republice se od roku 1993 pohybuje mezi 5 a 6 \% a v posledním roce, po mírném nárůstu v minulých letech dochází k opětovnému mírnému poklesu. “ $\mathrm{Za}$ rok 2012 bylo z celkového počtu 42764 osob trestně stíháno 2583 cizinců (z toho bylo

\footnotetext{
${ }^{109}$ Usnesení vlády ze dne 18. ledna 2016 č. 26, III., kapitola 1. Analýza aktuální situace v oblasti integrace cizinců na území České republiky, s. 5.

110 Usnesení vlády ze dne 9. ledna 2017 č. 11 k postupu při realizaci aktualizované Koncepce integrace cizinců - Ve vzájemném respektu v roce 2017, III. Postup při realizaci aktualizované Koncepce integrace cizinců - Ve vzájemném respektu v roce 2017 , s. 2.

111 Usnesení vlády ze dne 3. ledna 2018 č. 10 o Postupu při realizaci aktualizované Koncepce integrace cizinců - Ve vzájemném respektu v roce 2018, III. Postup při realizaci aktualizované Koncepce integrace cizinců - Ve vzájemném respektu v roce 2018 , s. 6.

112 Příloha č. 4, Bezpečnostní aspekty integrace cizinců na území České republiky.

113 Usnesení vlády ze dne 17. března 2008 č. 259 ke Zprávě o realizaci Koncepce integrace cizinců v roce 2007, Př́íloha č. 2 - Bezpečnostní aspekty integrace cizinců, s. 64.

114 Usnesení vlády ze dne 29. července 2015 č. 621, část III., Strategie migrační politiky České republiky.

115 Příloha č. 4, Bezpečnostní aspekty integrace cizinců na území České republiky.

116 Usnesení vlády ze dne 21. února 2007 č. 126, př́loha č. 2, Bezpečnostní aspekty integrace cizinců, s. 1.
} 
1379 občanů EU). V témže roce bylo z celkového počtu 71471 odsouzených osob 4913 cizinců ( $\mathrm{z}$ toho bylo 2858 občanů EU). ${ }^{117}$ Obdobně v roce 2016 bylo z celkového počtu 42655 osob trestně stíháno 2901 cizinců (z toho šlo o 1686 občanů EU). Odsouzeno bylo v témže roce celkem 61423 osob, z toho 5092 cizinců (z toho 3005 občanů EU). ${ }^{118}$

\section{VZTAHY MEZI CIZINCI A MAJORITNÍ SPOLEČNOSTÍ}

Přes řekněme rezervovaný postoj většinové společnosti k cizincům, ${ }^{119}$ popisují koncepce soužití majoritní společnosti s cizinci obecně jako nekonfliktní. Koncepce z roku 2011 popisuje Českou republiku jako zemi „s téměř nulovou hodnotou konfliktů mezi imigrační komunitou a domácím obyvatelstvem. Migrační realita posledních několika let s sebou nicméně přináśí riziko některých průvodních jevů jako je xenofobie, rasismus, extremismus či jiné projevy negativních postojů jedinců či skupin vůči cizincům. Trestné činy s rasovým podtextem jsou ojedinělé, ale v některých lokalitách s vyšší koncentrací cizincủ byly zaznamenány negativní postoje širší skupiny obyvatelstva vůči cizincům. "“20 Podobné hodnocení najdeme i v koncepci z roku 2016: „Česká republika je doposud zemí s téměř nulovou hodnotou konfliktů mezi komunitami cizinců žijících na území České republiky a majoritní společností. Pokud jde o subjektivní zkušenost cizinců s odmítáním ze strany majority, více než třetina cizinců (38 \%) uvádí zkušenost s xenofobií, naopak více než polovina cizinců (60 \%) projevy xenofobie ze strany Čechů nezaznamenala." $121 \mathrm{~V}$ témže dokumentu se dále dočteme, že ,většina cizinců Čechům důvěřovala (celkem 81 \%), lze tedy předpokládat, že mezi cizinci převládá spíše pozitivní vnímání členů majoritní společnosti. Současný stav společnosti v České republice cizinci hodnotí pozitivněji než současný stav v zemi jejich původu." 122

117 ČSÚ. Stíhané, obžalované a odsouzené osoby podle státního občanství v roce 2012 [online]. Dostupné z: https://www.czso.cz/documents/11292/39434086/12_c05t51.pdf/1e4ed2cc-69b3-4747-b03e $-4629 \mathrm{~d} 784 \mathrm{ed} 8 \mathrm{f}$ ?version=1.0.

118 ČSÚ. Stíhané, obžalované a odsouzené osoby podle státniho občanství v roce 2016 [online]. Dostupné z: https://www.czso.cz/documents/11292/39434086/16_c05t51.pdf/e070adb3-6e58-4d45-84bb-bf461fd 109f9? version=1.0.

119 Viz např. usnesení vlády ze dne 8. února 2006 č. 126, III. Aktualizovaná koncepce integrace cizinců, s. 24: „Většina státních občanů České republiky nepovažuje zvyšující se počet cizinců přicházejících do České republiky za pozitivní jev. Podíl těch, kteří příchod cizinců vnímají pozitivně, sice mírně vzrostl, celkově však česká společnost zůstává nadále názorově relativně uzavřená vůči imigraci a usídlování cizinců. Na straně druhé je pro tvorbu politiky integrace cizinců důležité zjištění, že česká společnost je pro přiznání veškerých práv, včetně možnosti získat státní občanství, těm cizincům, kteří se do české společnosti integrují." Viz rovněž každoroční sociologická šetření prováděná Centrem pro výzkum veřejného mínění (Sociologický ústav AV ČR), dostupná z: http://cizinci.cz/cs/2292-2016-vztah-ceske-verejnosti-k-narod nostnim-skupinam-zijicim.

120 Usnesení vlády ze dne 9. února 2011 č. 99, III., kapitola 1. Analýza aktuální situace v oblasti integrace cizinců na území České republiky, s. 14.

${ }^{121}$ Usnesení vlády ze dne 18. ledna 2016 č. 26, III., kapitola 1. Analýza aktuální situace v oblasti integrace cizinců na území České republiky, s. 8.

122 Tamtéž, s. 9. Koncepce čerpá z dat obsažených v op. cit. 106. 


\section{ZÁVĚR}

Jaké závěry lze dovodit z uvedených citací z koncepcí integrace cizinců? Na jedné straně je nepochybné, že stát učinil od roku 1999, kdy byly přijaty Zásady, celou řadu kroků, které měly na integraci cizinců pozitivní vliv. Za všechny zmiňme např. dorovnání postavení rodinných příslušníků (občanů třetích zemí) nemigrujících občanů ČR s rodinnými př́slušníky migrujících občanů EU. Nadto vnitrostátní právní úprava nakládá jako s rodinnými př́slušníky i s dalšími kategoriemi cizinců ve smyslu čl. 3 odst. 2 směrnice 2004/38/ES, kteří ovšem nejsou rodinnými př́slušníky dle čl. 2 odst. 2 téže směrnice.

Na straně druhé ovšem samy koncepce přiznávají, že v řadě oblastí integrace cizinců účinnost přijatých opatření pokulhává. To v podstatě potvrzuje široce uznávaný index integrační politiky (MIPEX) z roku 2015, který srovnává vládní politiky integrace cizinců na základě 167 kritérií v osmi oblastech (práce, vzdělávání, zdraví atd.). V mezinárodním srovnání integračních politik 38 členských států EU a dalších vyspělých zemí (např. USA, Austrálie či Japonsko) se Česká republika umístila na 23. místě. Nejhoršího hodnocení dosáhla Česká republika v kategorii politické participace cizinců a v kategorii vzdělávání. ${ }^{123}$

Pozitivně lze nepochybně vnímat, že od roku 2009 za podpory unijních peněz vznikla v krajích centra na podporu integrace cizinců. Poskytují cizincům komplexní integrační služby (právní a sociální poradenství, kurzy českého jazyka atd.) a pokrývají svojí činností 13 krajů České republiky vč. hlavního města Prahy. Na straně druhé jsme ovšem viděli, že např. v Praze kurzy českého jazyka zdaleka nepostačují k pokrytí poptávky, naopak v regionech se vyrovnávají s poklesem zájmu. Nadto, od roku 2015 se centra „,potýkají se zásadním propadem financování ze strany EU (snížení alokovaných prostředků nového Azylového, migračního a integračního fondu na polovinu)““. ${ }^{124}$

Obecně si lze položit otázku, zda jsou prostředky vynakládané státem na integraci cizinců dostatečné. Roční částky na integraci cizinců se pohybují v rozmezí od 20 do 25 milionů korun. V roce 2005 to však bylo jen 12 milionů, v roce 2011 dokonce jen 10 milionů. K nárůstu došlo až v posledních třech letech, který zřejmě souvisí s propadem financování z unijních zdrojů (v letech 2016 až 2018 byla každoročně vyčleněna na integraci cizinců částka 54290290 Kč). S ohledem na výzvy, kterým úspěšná integrace cizinců v ČR čelí, i na samotné počty cizinců, které narostly od roku 1989 třináctinásobně, mám pochybnosti o dostatečnosti vynakládaných částek. Domnívám se, že mnohem důležitější roli sehrálo čerpání z unijních fondů (viz např. Evropský fond pro integraci cizinců z třetích zemí, díky němuž mohla vzniknout centra; v minulosti Iniciativa Equal či OPLZZ atd.).

Omezené vnitrostátní zdroje určené na integraci cizinců šly povětšinou na projekty nevládních organizací. Je nepochybné, že se za ně realizovalo mnoho skvělých a užitečných projektů, které integraci cizinců napomohly. Závažným problémem, který se nepodařilo beze zbytku vyřešit ani do současnosti, je kontinuita financování projektů.

${ }^{123}$ Hodnocení České republiky je dostupné z: http://www.mipex.eu/czech-republic.

124 Usnesení vlády ze dne 18 . ledna 2016 č. 26, III., kapitola 1. Analýza aktuální situace v oblasti integrace cizinců na území České republiky, s. 10, 11. 
Koncepce správně zdůrazňují zásadní roli neziskového sektoru. Ten se však každoročně potýká s byrokracií spojenou s přidělováním dotací. Pokud dochází k jejich přidělování ve druhém i třetím čtvrtletí roku, na který byla dotace určena, má to závažné dopady na efektivitu realizovaných projektů a na samotnou činnost nevládních organizací (udržení personálu, návaznost projektů atp.).

Velké rezervy jsou v zapojení samospráv. Jistě, vznikli např. krajští koordinátoři integrace (integrací cizinců se zabývají taktéž některá města), jejich činnost však není efektivní. Ano, máme tu integrační (dříve emergentní) projekty obcí, je v nich ovšem zapojeno pouze 10 obcí. Personální pokrytí agendy integrace cizinců je nedostatečné i na jednotlivých ministerstvech. Kritika ministerstva vnitra ostatních resortů je v tomto ohledu oprávněná. Na př́kladu zajištění bezplatné jazykové přípravy dětem občanů třetích zemí na základních školách v gesci MŠMT jsme viděli, že realizace některých integračních opatření se může vléci po mnoho let. A podobných př́kladů jsou jednotlivé koncepce plné. Doposud se nepodařila adekvátně vyř̌šit účast vybraných kategorií cizinců (zejména dětí) na veřejném zdravotním pojištění. Nesplněny zůstaly rovněž sliby ohledně účasti cizinců s trvalým pobytem ve volbách do místních zastupitelstev. Stát neumožňuje občanům EU s přechodným pobytem účast ve volbách do místních zastupitelstev, což jednoznačně odporuje unijnímu právu.

Závažným problémem, který přetrvává, je orientace cizinců $\mathrm{v}$ právech a povinnostech souvisejících $\mathrm{s}$ jejich pobytovým statusem. Nelze popř́it, že v této oblasti byla v posledních letech přijata řada pozitivních opatření. Zlepšila se dostupnost informačních (zejména internetových) zdrojů, v nichž mohou cizinci najít informace o jednotlivých pobytových titulech. ${ }^{125}$ Pracoviště odboru azylové a migrační politiky ministerstva vnitra (včetně provozu telefonické infolinky a hovoří se o spuštění internetového objednávání) představují nepochybně vstřícnější prostředí pro podávání žádostí než předchozí služebny cizinecké policie. Naštěstí jsou pryč doby před rokem 2011, kdy měla agendu většiny dlouhodobých pobytů na starosti právě cizinecká policie a kdy jsme byli zejména v Praze před pracovišti cizinecké policie svědky front čítajících stovky cizinců, jejichž pořadí organizovaly mafiánské struktury. Zákon o pobytu cizinců se však stal nesrozumitelnou normou pro odborníka - právníka, který se v cizineckém právu pohybuje řadu let, natožpak pro cizince - neprávníka. To má za následek, že se do značné míry nepodařilo odbourat závislost cizinců na nejrůznějších pochybných zprostředkovatelích (bez právního vzdělání), kteří za úplatu a často nekvalitně a $\mathrm{k}$ jejich škodě vyřizují za cizince nejrůznějši pobytové záležitosti. Pobytová agenda cizinců se stala výnosným byznysem pro řadu advokátních kanceláŕí a někdy lze mít pochybnosti o kvalitě a profesionalitě jejich služeb.

Závažný problém zejména pro Ukrajince a Vietnamce (tzn. dvě nejpočetnější cizinecké komunity z třetích zemí), kteří na území ČR pobývají na základě dlouhodobého či trvalého pobytu, představovala nefunkčnost systému Visapoint $\mathrm{v}$ jejich domovských zemích. Bránila jim realizovat jejich právo na sloučení s jejich nejbližšími rodinnými

${ }^{125}$ Viz např. informace pro cizince na webových stránkách ministerstva vnitra (rovněž v ruské a anglické jazykové mutaci), dostupné z: http://www.mvcr.cz/clanek/sluzby-pro-verejnost-informace-pro-cizince -informace-pro-cizince.aspx. 
př́islušníky. ${ }^{126}$ Lze se ptát, jaký má reálný dopad jedno z pozitivních opatření státu, které jde nad rámec závazků vyplývajících z unijního práva a které umožňuje nezletilým dětem cizinců s trvalým pobytem podat žádost o trvalý pobyt ihned poté, co jejich rodič získal trvalý pobyt $\mathrm{v}$ ČR (a nemusí tedy nejdřive žádat o dlouhodobý pobyt za účelem sloučení rodiny), pokud jim bylo v důsledku nefunkčnosti systému Visapoint znemožněno žádost podat. Zároveň okolnosti provázející fungování uvedeného systému v zemích jako je Vietnam či Ukrajina, které nutily k zaregistrování se k podání žádosti využivat za nemalé částky služeb zprostředkovatelů, vytvářely již na vstupu nelichotivý obrázek o poměrech panujících v České republice. Zároveň se alespoň prozatím nezdá, že by po zrušení Visapointu došlo k podstatnému zlepšení poměrů.

Pokud jde o nabývání státního občanství, lze nepochybně vnímat pozitivně možnost dvojího státního občanství a zjednodušené nabývání občanství pro cizince druhé generace, které zavedla od 1. ledna 2014 nová státoobčanská právní úprava zákonem č. 186/2013 Sb. Na straně druhé vnímám jako problematickou soudní výluku v př́ípadě, kdy byla žádost zamítnuta na základě stanoviska bezpečnostních složek. ${ }^{127}$ Spornou je rovněž právní úprava nabytí občanství dítětem na základě souhlasného prohlášení rodičů o určení otcovství v př́ipadech, kdy matka není občankou EU či nemá trvalý pobyt. $\mathrm{V}$ těchto prrípadech, tedy pokud je např. matkou dítěte třetizemka pobývající v ČR na základě povolení $\mathrm{k}$ dlouhodobému pobytu, zákon vyžaduje prokázání otcovství genetickou zkouškou formou znaleckého posudku podle zákona o znalcích a tlumočnících (lidově tzv. testem DNA).

S ohledem na rozsah př́spěvku nelze popsat všechny další příklady, kdy je právní úprava vůči cizincům (včetně občanů EU) v rozporu s unijním právem či jinak problematická. Za všechny zmiňme ještě nap̌r. opatření některých samospráv, která v rozporu s unijním právem odpírají občanům EU či cizincům z třetích zemí s postavením dlouhodobě pobývajícího rezidenta dle směrnice 2003/109/ES př́stup k obecnímu bydlení. ${ }^{128}$ Aktuálně lze upozornit i na poslední novelizaci zákona o pobytu cizinců zákonem č. 222/2017 Sb., kterou došlo v několika ohledech (uplatnění zásady proporcionality, automatická spojitost mezi odsouzením za trestný čin a ukončením pobytu, bránění rodinnému př́slušníkovi občana ČR podat v určitých príípadech žádost o přechodný pobyt na území) ${ }^{129} \mathrm{k}$ přijetí právní úpravy, která je jednoznačně rozporná s unijním právem.

Přes výše uvedené, a možná paradoxně, probíhá doposud integrace cizinců v České republice převážně úspěšně. Viděli jsme, že cizinci se podílejí na čerpání sociálních dávek pouze minimálně, jinými slovy sociální systém významně nezatěžují, naopak svými odvody pomáhají vytvářet prostředky, z nichž je tento systém financován. Cizinci

\footnotetext{
${ }^{126} \mathrm{~V}$ podrobnostech viz op. cit. 43.

127 Nejvyšší správní soud (sp. zn. 2 As 64/2017) se v této věci obrátil na Ústavní soud (řízení vedeno pod sp. zn. Pl. ÚS 39/17), nebot dospěl k závěru, že ,ustanovení § 26 zákona o státním občanství vylučující soudní přezkum rozhodnutí o neudělení státního občanství z důvodu ohrožení bezpečnosti státu je v rozporu s ústavním pořádkem České republiky“.

128 Viz šetření ochránkyně vedené pod sp. zn. 5080/2015/VOP/EN, 1677/2017/VOP/EN a 3893/2015 /VOP/EN (zpráva z posledně uvedeného šetření je dostupná ve veřejně př́stupné Evidenci stanovisek ombudsmana http://eso.ochrance.cz/Nalezene/Edit/4814).

129 Ústavnost posledně uvedené změny právní úpravy byla již napadena u Ústavního soudu (ř́izení vedené pod sp. zn. Pl. ÚS 41/17).
} 
rovněž nemají problém s integrací na trhu práce. Nepředstavují bezpečnostní hrozbu a s ohledem na jejich počty nevybočuje ani jejich podíl na páchání celkové trestné činnosti. V této souvislosti navíc připomeňme, že (alespoň novější) statistiky nikterak nerozlišují mezi dlouhodobě pobývajícími cizinci (tzn. zejména s trvalým/dlouhodobým pobytem) a ostatními cizinci, kteří v ČR pobývají krátkodobě bez víza, na krátkodobé vízum či dokonce nelegálně. Podíl cizinců, kteří tvoří cílovou skupinu integrace cizinců, na páchání trestné činnosti, tak bude ještě nižší. Přes do určité míry rezervovaný postoj veřejnosti $\mathrm{k}$ cizincům hodnotí koncepce soužití majoritní společnosti s cizinci obecně jako nekonfliktní.

Cizinci mají přes všechny bariéry a problémy, kterým při svém pobytu v České republice čelí, zájem se integrovat. Aktuální průzkum veřejného mínění z roku 2015 mezi třemi nejpočetnějšími skupinami cizinců z třetích zemí (Ukrajinci, Vietnamci a Rusy) žijících na území České republiky prokázal, že se většinově chtějí integrovat do majoritní společnosti, pouze $8 \%$ respondentů se vyjádřilo opačně. ${ }^{130}$ Většina z těchto cizinců Čechům důvěřuje. ${ }^{131}$ Zároveň bylo zjištěno, že stav společnosti v České republice vnímala většina cizinců spíše pozitivně (52 \%) až pozitivně (34 \%). Negativně současný stav naší společnosti hodnotilo pouze jedno procento cizinců zkoumaných státních příslušností. ${ }^{132} \mathrm{Za}$ velmi důležité lze považovat i zjištění, že minimálně u uvedených tř́ skupin cizinců se jejich hodnotový rámec shoduje s hodnotami sdílenými většinovou společností: „Z volného srovnání hodnotových rámců majority a sledovaných minorit lze konstatovat podobnost $\mathrm{v}$ jejich vnímání hierarchie zkoumaných hodnot, přičemž u majority dochází k vyšší rozmělněnosti vnímání důležitosti hodnot, jakými jsou rodina a práce." 133

Minimálně od dob tzv. uprchlické krize v roce 2015 i v České republice téma migrace velmi silně rezonuje v celospolečenských debatách, včetně těch politických. Postoj (at' už skutečný či jen ten připisovaný, „,nálepkujícíc) k migraci, k islámu do značné míry rozhoduje o úspěchu ve volbách do Poslanecké sněmovny či naposledy v prezidentských volbách. U některých politických stran je uvedený postoj středobodem jejich politického programu. Je velmi smutné, že veškeré debaty, které navíc často vykazují fatální neznalost a nepochopení základních pojmů (např. směšování pojmů i/migrant a uprchlík), se smrskávají na postoj České republiky k tzv. uprchlickým kvótám (často zmatečně popisovaným jako migrační kvóty). Jako by tu oněch víc než půl milionu prozatím vesměs dobře integrovaných cizinců neexistovalo. Jejich počty přitom narůstají každým rokem. Podle střední varianty projekce obyvatelstva Českého statistického úřadu bude k 1. 1. 2066 žít na našem území 1,49 milionu cizinců a budou tvořit 18,1 \% populace. ${ }^{134}$ Jejich integrace představuje pro Českou republiku nepoměrně náročnější výzvu než př́ipadné prrijetí několika tisíc uprchlíků. 135

130 Op. cit. 106 , s. 71.

131 Tamtéž, s. 72.

132 Tamtéž, s. 85 .

133 Tamtéž, s. 95.

${ }^{134}$ Dostupné z: https://www.czso.cz/documents/10180/20554203/400709a8.pdf/714d7953-3a40-4b43-83b7 $-9921 \mathrm{a} 59 \mathrm{a} 3 \mathrm{db} 8$ ? version $=1.0$.

135 Je smutným paradoxem, že právě v letech 1998-2002, kdy byl současný, resp. nově zvolený prezident premiérem, přijímala Česká republika nejvyšší počty žadatelů o azyl (mezinárodní ochranu) ve své 
Jsem si vědom poctivého a neúnavného úsilí celé řady jednotlivců at’ už ze státní správy, samospráv či neziskového sektoru na poli integrace cizinců. Přesto si s ním do budoucna nevystačíme. Pokud má Česká republika v budoucnu úspěšně absorbovat rostoucí počty cizinců, vyhnout se závažným konfliktům mezi majoritní společností a cizineckými komunitami a zabránit zneuživání tématu migrace $\mathrm{k}$ politické propagandě a k vytváření atmosféry strachu, pokud má udržet projevy xenofobie a rasismu pod kontrolou, musí se co nejdříve stát integrační politika státu vůči cizincům v klíčových oblastech integrace jednou ze skutečných vládních priorit, včetně tomu odpovídající alokace finančních prostředků a vyčlenění dalších kapacit (personálních, organizačních atd.) nejen na úrovni státní správy, ale i samospráv a nevládních organizací.

\begin{tabular}{|l|l|}
\hline Integrace cizinců & Integration of foreigners \\
\hline Integrační politika & Integration policy \\
\hline Koncepce integrace cizinců & Policy for the integration of foreigners \\
\hline Zásady koncepce integrace cizinců & Principles of foreigners integration \\
\hline Multikulturní společnost & Multicultural society \\
\hline Integrační opatření & Integration measures \\
\hline Znalost českého jazyka & Knowledge of the Czech language \\
\hline Vztahy mezi komunitami & Relations among communities \\
\hline Socio-kulturní orientace ve společnosti & Sociocultural orientation within society \\
\hline Ekonomická a sociální soběstačnost & Economic and social self-sufficiency \\
\hline Třetizemci & Third country nationals \\
\hline Adaptačně integrační kurz & Adaptation and integration classes \\
\hline Cílová skupina integrace & Target group of integration \\
\hline Veřejné zdravotní pojištění & Public health insurance \\
\hline Volby do místních zastupitelstev & Municipal elections \\
\hline Nevládní organizace & Non-governmental organizations \\
\hline
\end{tabular}

JUDr. Pavel Poř́zek, Ph.D.

Kancelář veřejného ochránce práv

pavel.porizek@ochrance.cz

novodobé historii (v roce 2001 dokonce rekordní): 1998 - 4086, 1999 - 7218, 2000 - 8794, 2001 - 18094 , 2002 - 8484. A pokud bych chtěl být jízlivý (s ohledem na častou používanou tzv. „muslimskou kartu“), jen v roce 1999 požádalo o azyl v ČR 2.312 (32\% všech žadatelů za ten rok) osob z Afghánistánu, což předpokládám, byli vesměs muslimové (v roce 2000 to bylo 1121 žadatelů z Afghánistánu, kteří tvořili 13 \% všech žadatelů). Naproti tomu počty žadatelů z posledních let, včetně pro EU kritického roku 2015, zdaleka nedosahují ani počtů žadatelů o azyl z Afghánistánu v roce 1999 (2010 - 833, 2011 - 756, 2012 753, 2013 - 707, 2014 - 1156, 2015 - 1535, 2016 - 1478, do ř́jna 2017 - 1229). Každoroční statistiky žadatelů o mezinárodní ochranu jsou dostupné na webu ministerstva vnitra: http://www.mvcr.cz/clanek /mezinarodni-ochrana-253352.aspx. Uvedená čísla dokládají, jak výrazně si Česká republika pomohla zapojením se do dublinského systému, který přenesl zátěž za vyřrizování žádostí o mezinárodní ochranu na ty členské státy, jimiž žadatelé vstupují na území EU. 